
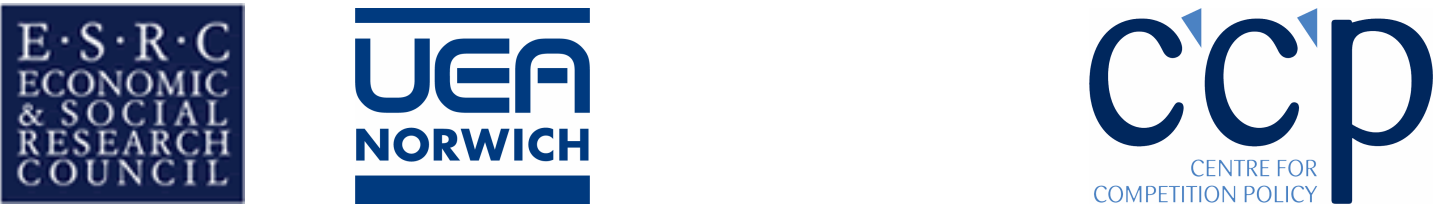

\title{
The Role of State Attorneys General in U.S. Antitrust Policy: Public Enforcement through Private Enforcement Methods
}

by

Firat Cengiz

ESRC Centre for Competition Policy and School of Law, University of East Anglia

\section{CCP Working Paper 06-19}

Abstract: This paper discusses the role of State Attorneys General in the enforcement of the federal antitrust laws in the U.S. It provides a substantial background on the doctrinal roots of the State Attorney General's power to enforce federal antitrust laws. Then, it analyses the advantages of the state enforcement mechanism both in terms of providing redress to consumers and deterrence to undertakings. Building upon this framework and the empirical data on state enforcement, the paper critically analyses the proposals of the Antitrust Modernization Commission on state enforcement. It suggests that the State Attorneys General constitute a vital part of the federal antitrust scheme, and problems associated with their enforcement efforts are largely over-stated. Even if there really is a danger of over-enforcement, the paper argues that the problem can be solved through less dramatic amendments.

November 2006

JEL Classification Codes: K21, K23, K41, K42

Keywords: Parens patriae, State Attorney General, Antitrust Modernization Commission, Hart-Scott-Rodino, Antitrust Improvements Act, indirect purchasers, treble damages, class actions.

Acknowledgements: The author is grateful to Dr. Michael Harker, Dr. Lindsay Stirton, Dr. S. Altug Kesikli and Prof. Morten Hviid for their helpful comments and suggestions. All the errors remain hers. She also greatly acknowledges support of the ORSAS Scheme of the British Government and the Studentships Scheme of the Faculty of Social Sciences of UEA. The support of the Economic and Social Research Council is also gratefully acknowledged.

\section{Contact details:}

Firat Cengiz, Centre for Competition Policy, University of East Anglia, Norwich, NR4 7TJ, UK.

f.cengiz@uea.ac.uk 


\section{INTRODUCTION}

This paper analyses the role of the State Attorneys General (State AGs) in U.S. antitrust policy enforcement. The position of the State AG deserves interest for a couple of reasons. First, although being public officials, they utilise private enforcement methods. Second, their position and activities are currently under the scrutiny of the U.S. Antitrust Modernization Commission, and the current tendency seems to be towards centralisation. The scope of the paper is limited to the activities of the State AGs against Sherman Act violations.

This paper starts with a brief description of the office of the State AGs. In contrast to the competition authorities in Europe, which are generally administrative in nature and specialise in the enforcement of the competition rules, the State AGs are political in their nature, and they pursue a much more comprehensive agenda.

Afterwards, the paper analyses the doctrine of parens patriae in its historical structure, which is the main source of authority of the State AGs in enforcement of federal antitrust law. It is emphasised that the doctrine has experienced substantial transformation over time, as it has evolved to a source of deterrence and redress, whereas it used to be a mechanism of federalism.

Then, putting it into the context of antitrust, the paper discusses features of modern antitrust enforcement through parens patriae actions. The strengths of the parens patriae mechanism, compared to class actions, methods of damage distribution, degree of control exercised by the courts, and limitations of parens patriae actions, particularly the position of indirect purchasers in federal law, constitute the main subjects of discussion. Throughout the section it is underlined that although using private enforcement methods, State AGs enforce federal antitrust laws for public purposes, hence, they have been given considerable discretion to direct their enforcement efforts. 
Next, the paper examines empirical data regarding enforcement efforts of the State AGs between the years 1980 and 2006. Diversity of the types of violations the State AGs target, the trend towards constant inter-state and federal-state cooperation, and the efforts of the State AGs to mix and match possibilities offered by federal and state laws in order to maximise their authority are the most striking conclusions of the empirical section. The paper then briefly discusses the Tobacco and Microsoft cases which seem to pose exceptions to the positive trend in state enforcement, and as a result, dramatically affect the national perception towards the role of the State AGs.

Eventually the paper discusses the proposals of the Antitrust Modernization Commission to enhance the effectiveness of current enforcement structure. In addition to the proposals addressing state enforcement directly, proposals on indirect purchasers are also discussed, albeit only in terms of their possible impacts on state enforcement. The Antitrust Modernization Commission is criticised for going to the extreme in the lack of any convincing empirical evidence on the costs and benefits of state enforcement. Besides, the position of the Commission seems to be inconsistent as it proposes to restrict parens patriae authority on the one hand, and to level the playing field on the other in the context of actions by indirect purchasers for treble damages. The paper proposes an alternative solution; one of improved judicial scrutiny through adoption of a judicial review standard tailored to the dynamics of parens patriae actions with a special emphasis on conflicts between the state and federal enforcers.

\section{STATE ATTORNEYS' POSITION, POWERS and DUTIES IN GENERAL}

The history of the State AGs traces back to colonial times where attorneys were appointed by the King of England to perform the function of the Attorney General of England in the colonies; that is, to represent the interests of the crown in every venue including the judiciary and the legislature. ${ }^{1}$ During the

\footnotetext{
${ }^{1}$ Lacy H. Thornburg (1990), Changes in the State's Law Firm: The Powers, Duties and Operations of the Office of the Attorney General, Campbell Law Review, 12(3): 343-381, at 346; Scott M. Matheson, Jr. (1993), Constitutional
} 
foundation of the federation, the state AGs were kept as an institution but their function and position were subject to significant transformation. Today, the state AGs hold a hybrid position within the mainstream of state politics comprising of different political and legal functions. Whereas during the colonial times the main objective of the AG was to represent and protect the interests of the King, after the American revolutionary period which shifted the source of sovereignty from the King to the people, it has become the people who possess the main benefit to be protected by the state AGs. ${ }^{2}$ The same forces, together with the 'Jacksonian' democracy movement, have shaped the method of the appointment of the State AGs as well. ${ }^{3}$ Today, the State AGs are elected through popular voting in 48 states; in five they are appointed by the Governor; in Maine by the legislature; and in Tennessee by the State Supreme Court. ${ }^{4}$

Although in most of the states the State AGs are seen as a part of the executive, they perform additional quasi-legislative and prosecutorial duties and do not generally constitute a part of the Governor's cabinet in contrast to other units of the executive. ${ }^{5}$ They are generally characterised as the "chief legal officers of [their] jurisdictions". 6 Except for Connecticut, Indiana, Oregon, Vermont and Wyoming, the State AGs' functions and duties are defined and prescribed by the State constitutions. ${ }^{7}$ In general, their functions can be divided into three categories: legal advice, litigation and administrative duties. ${ }^{8}$

In most states, state legislatures and the units of the executive branch are entitled to ask for the legal opinion of the state AGs. Through their function of providing legal advice, the State AGs influence the state policies to a great extent. $^{9}$ Those requests for legal opinion may relate to daily legal problems

Status and the Role of the State Attorney General, University of Florida Journal of Law and Public Policy, 6(1):1-31at 2; Arlen C. Christenson (1970), The State Attorney General, Wisconsin Law Review, 2:299-340, at 300.

${ }^{2}$ Matheson, Jr., id., at 12.

${ }^{3}$ Id., at 6.

${ }^{4}$ Id.; Christenson, supra note 1, at 298.

${ }^{5}$ Christenson, id., at 300 ; Thornburg supra note 1, at 357-58; Matheson, Jr., supra note 1 , at 8.

${ }^{6}$ Christenson, id., at 300; Thornburg, id., at 356.

${ }^{7}$ Earl H. DeLong (1934), Powers and Duties of the State Attorney-General in Criminal Prosecution, Journal of the American Institute of Criminal Law and Criminology, 25(3):358-400, at 359.

${ }^{8}$ Christenson, supra note 1 , at 301 ; Thornburg, supra note 1, at 345 ; Matheson, Jr.,, supra note 1 , at 3.

${ }^{9}$ Christenson, id., at 299, 311; Thornburg, id., at 357-58 
such as the conflicts between different administrative units which occur when they perform their duties, as well as to high policy issues such as the legislative action to be taken to deal with a particular political problem. There is a consensus in the literature that legal advice of the State AGs is generally taken into consideration under ordinary circumstances. ${ }^{10}$ At times, legal opinion of the state AGs, especially those regarding conflicts between administrative units, may even set the only official interpretation on a particular legal question - as those matters generally remain unlitigated - and influence the stance of the state courts in subsequent cases. ${ }^{11}$ In some states, the AGs are also given the authority to mediate conflicts between administrative and political units, and as a result they get involved in the administrative politics more frequently. ${ }^{12}$ Besides, in most states, either because they are given that duty specifically by the state law or because it is found inappropriate to ignore the complaints of the citizens, particularly when it is considered that they are appointed by popular vote, they function as a kind of ombudsman in mediation of the conflicts between the citizens and the state executive or administrative units. $^{13}$

The office of the State AG has a very high burden of litigation involving both state and federal law. Therefore, some define the office as the "largest public benefit law firm of the state". ${ }^{14}$ The office of the State AG gets involved in litigations when the benefits of the state and/or her citizens are at stake. First of all, they are generally required to interfere with the litigations both in the state and federal courts when a political or administrative division of the state or a state official is a party to the suit ${ }^{15}$. Second, they pursue litigation to protect the wellbeing of their citizens before the federal and state courts. ${ }^{16}$ In general, this function stems from and had been developed through the application of the 'parens patriae' doctrine which is analysed in detail in the following section. The litigation burden of the office of State AG has greatly increased since the 1970s to include new domains such as antitrust,

\footnotetext{
${ }^{10}$ Christenson, id., at 309.

${ }^{11}$ Christenson, id., at 327-28.

${ }^{12}$ Id., at 333 .

${ }^{13}$ Id., at 336.

${ }^{14}$ Id., at 300 , Thornburg, supra note 1 , at 362 .

${ }^{15}$ Christenson, id., at 306; Thornburg, id., at 347; Matheson, Jr., supra note 1, at 3.

${ }^{16}$ Christenson, id., at 311; Thornburg, id., at 347; Matheson, Jr., id., at 3.
} 
consumer protection, environmental protection and public nuisance as a result of the increasing value given to those policies both by the state and federal levels ${ }^{17}$. The litigation function of the State AGs largely includes civil matters, as in most of the states criminal enforcement is exclusively the duty of the District Attorneys. Nevertheless, there are some states where direct involvement of the State $A G$ is required in criminal matters, and in some others they affect the criminal proceedings and ultimately criminal policy through their supervisory powers on the District Attorneys. ${ }^{18}$

The State AGs' administrative duties and powers differ from state to state. For instance, where regulated, the office of the State AG has the power to set the rates for utilities. $^{19}$ In general however, the administrative duties largely include those related to law enforcement functions.

Not surprisingly, the State AGs' powers and duties are not strictly restricted to those specifically prescribed by the state constitutions and legislations. As they have their genesis back in the English common law, so do their powers according to the stare decisis in most states. Although it is generally acknowledged that the State AGs possess the powers granted by the common law besides those recognised by the modern American federal and state law, the degree and authority of such power differs from state to state. ${ }^{20}$ The general tendency is "to prevent any overlapping of powers in the absence of any definitive legislative grant of concurrent power". ${ }^{21}$ Thus, generally the State AGs enjoy those powers stemming from common law as long as those powers are not granted to any other authority or prohibited to the State AG explicitly by the state law. However, extreme examples also exist, such as Illinois, where the legislative is hindered in taking away the common law powers of the State $A G,{ }^{22}$ and Washington, where common law powers are not recognised at all. ${ }^{23}$ Parens patriae authority of the State AGs constitute

\footnotetext{
${ }^{17}$ Christenson, id., at 316-317; Thornburg, id. at 357, 361; Matheson, Jr., id., at 3.

${ }^{18}$ DeLong, supra note 7 , at 379 .

${ }^{19}$ Christenson, supra note 1 , at 304

${ }^{20}$ Thornburg, supra note 1, at 356; Matheson, Jr., supra note 1, at 12; DeLong, supra note 7, at 361-62.

${ }^{21}$ Earl H, DeLong, id., at 367.

22 Saxby v. Sonneman, 318 Illinois 600, 606, 149 N.E. 526 (1925) at 529.

${ }^{23}$ State v. Seattle Gas and Electric Company, 28 Washington 488, 495, 68 Pac., 946 (1902), at 949.
} 
the most famous one among the common law authorities both in terms of doctrinal interest and practical policy enforcement purposes.

In summary, the State AGs possess a unique position within the political structure of the state. Besides being the chief law enforcers in their state, they also enjoy powers which give them the ability to influence the making of the state policies. They shoulder a litigation burden, including but not solely consisting of, antitrust law. Hence, both for organic and functional purposes, they are largely different from the national competition authorities in Europe, which are generally administrative authorities in their nature and specialise in antitrust enforcement. Below, the structure of Alabama State AG's office is given as an illustration of the wide variety of policies which a State $A G$ is responsible to deal with as everyday business. ${ }^{24}$

Office of the Alabama State Attorney General (Mr. Troy King)

1

1) Administrative Hearings Division: As a neutral panel of administrative judges this panel serves in administrative hearings for state agencies, boards and commissions.

2) Administrative Services Division: This division gives administrative support to the office.

3) Capital Litigation Division: This division represents the State in all appeals in state and federal courts in which a criminal defendant has received a death sentence.

\footnotetext{
${ }^{24}$ The information given in the chart is taken from the official website of the Attorney General of Alabama, and is available at http://www.ago.state.al.us/about divisions.cfm. Although there is no special division dealing with antitrust enforcement, assistant attorneys from different divisions such as the Consumer Affairs and White Collar Crimes Division, and the Law Enforcement Unit, together with the State Attorney General, are involved in antitrust investigations.
} 
4) Constitutional Defence Division: This division defends the State in federal and state courts where a constitutional question is raised.

5) Consumer Affairs Division: Provides protection to the consumers by serving as a mediator in consumer complaints, investigating the allegations of fraud or any other illegal activity by the business and offering information to the consumers.

6) Criminal Appeals Division: As the largest division of the office it represents the State in all criminal cases not involving death sentence.

7) Environmental Division: This division investigates complaints involving pollution, illegal hazardous waste, and other dangerous environmental concerns. Its lawyers file either a civil complaint or prosecute criminally. Environmental lawyers also develop proposed environmental regulation and legislation.

8) Executive Division: The Executive Division houses the executive staff, including the Attorney General. The Chief Deputy Attorney General oversees all legal staff for the Office and keeps abreast of the day-to-day legal matters.

9) Family Protection Unit: Consisting of the Child Abuse and Exploitation, Elder Abuse and Exploitation, Consumer Fraud, and Welfare Fraud departments, the Family Protection Unit takes civil and criminal action in collaboration with other state organisations to provide a healthy family environment to the citizens.

10) General Civil and Administrative Law Division: This division represents the State in civil actions in all courts both as the plaintiff and the defender in matters including prisoner litigation, administrative hearings, contacts and commercial transactions. The Civil Division also encompasses the Utilities and the Consumer Affairs Sections.

11) Investigations Division: The Division investigates public corruption and white-collar crime cases as well as violent crimes and drug cases.

12) Law Enforcement Unit: This unit coordinates annual state-wide law enforcement training on constitutional and criminal procedures, reviews and answers most constituent complaints lodged against local and county law enforcement agencies, on the behalf of the Attorney General, provides assistance to law enforcement agencies upon request and attends law enforcement conferences and association meetings on the behalf of the Attorney General's office, to stay abreast of issues affecting law enforcement. 
13) The Opinions Division: Through the division the Attorney General, upon written request, furnishes written opinions on questions of law to the Governor, the other constitutional officers, the heads of state departments, agencies, boards and commissions, the members of the Legislature, and thousands of other local public officials and political subdivisions.

14) Medicaid Fraud/Welfare Fraud Division: The Unit is responsible for the investigation and prosecution of allegations of fraud and abuse by healthcare providers against the Alabama Medicaid Agency.

15) Public Corruption and White Collar Crime Division: The division comprises of prosecutors specially trained in the prosecution of public corruption, election fraud, bid-rigging, complex economic crimes, and ethics code violations. This division also assists the Alabama Securities Commission and the Judicial Inquiry Commission in their prosecutions.

16) Southern Environmental Enforcement Network: The Network is a regional alliance of forty-five agencies from eleven Southern states. The Network was created by the participating states to support the effective enforcement of environmental laws, with an emphasis on criminal enforcement.

17) Victim Assistance Division: The division provides state-wide assistance to victims of violent crime.

18) Violent Crimes Division: The division consists of prosecutors represent the State in the investigation and prosecution of violent crimes, especially murder and rape, throughout the State.

\section{THE DOCTRINE OF PARENS PATRIAE}

The State AGs are given the authority to enforce the federal antitrust policy by the Hart-Scott-Rodino Antitrust Improvements Act (HSR Act) which recognises their position of 'parens patriae'. The doctrine of parens patriae has remarkable historical roots and has experienced substantial transformation to serve different purposes before being utilised as an enforcement mechanism within the modern antitrust structure. At first the 
Supreme Court borrowed the concept from English common law to reinforce the federal vision, and then Congress discovered its utility as a source of extra deterrence to antitrust violations, and redress for the injured consumers.

\section{A. Parens Patriae in Common Law}

Literally, parens patriae means "the father of the country", and in its roots it refers to the Prerogative Regis or the royal prerogative of the King of England as the guardian of his people. ${ }^{25}$ In common law, the King was deemed to be "personally sovereign" and to have "pre-eminence over all within the realm". ${ }^{26}$ Specifically, however, due to his position as parens patriae, the King had become the guardian of those who are not able to protect their own interests, as he was believed to be "the general guardian of all infants, idiots, and lunatics", and "the superintended of all charitable uses in the Kingdom". ${ }^{27}$ Due to his position as parens patriae, the King was empowered to control legal and real persons falling under any one of these categories and to take them under his custody. ${ }^{28}$

\section{B. Supreme Courts Federal Vision: Early American Roots of Parens}

\section{Patriae}

Although adopting the concept from common law and sticking to the consideration that one has the prerogative to sustain the well-being of those under his sovereignty, the American vision of parens patriae has developed to accomplish largely distinct aims and over broader categories of subject matters. The United States Constitution gave original jurisdiction to the Supreme Court to hear the conflicts between the states and between one state and the citizen of another. ${ }^{29}$ This provision was presumably adopted as a precaution to keep the constituent units of the federation together by preventing the states from engaging in retaliatory activities in their sovereign

\footnotetext{
${ }^{25}$ Michael Malina, Michael D. Blechman (1970), Parens Patriae Suits for Treble Damages under the Antitrust Laws, Northwestern University Law Review, 65(2):193-231., at 197; George B. Curtis (1975), The Checkered Career of Parens Patriae: The State as a Parent or Tyrant?, DePaul Law Review, 25(3):895-915, at 895-96.

${ }^{26}$ Curtis, id., at 896.

${ }^{27}$ W. Blackstone, Commentaries, 47-84 (12 ${ }^{\text {th }}$ Ed. E. Christian Ed., 1974); J. Chitty (1820), A Treatise on the Law of the Prerogative of the Crown 155.

${ }_{28}$ J. Chitty, id.; Arthur F. Owens (1972), The Role of the States in Treble Damage Recovery under the Federal Antitrust Laws: Rule 23 Class Actions and Parens Patriae, Drake Law Review, 22(1):155-166 at161-162; Jack Ratliff (1999), Parens Patriae: An Overview, Tulane Law Review, 74(5):1847-58at 1850-5.

${ }_{29}$ U.S. Const. Art. III § 2.
} 
capacities. Through a series of cases involving teleological interpretation, the Supreme Court established the position of parens patriae of the states, and expanded its original jurisdiction to solve the conflicts where the quasisovereign ${ }^{30}$ interests of a state is at stake.

Earlier parens patriae cases share some common characteristics. First of all, the conflicts generally stemmed from trade restrictions or negative externalities ${ }^{31}$ particularly caused by unregulated industries as those cases had been brought in the early years of the federation when unity was still an unfulfilled objective. Second, and as a natural result of the desire to sustain political and economic integration, the Supreme Court borrowed the concepts of international law frequently, and analysed the types of remedies which the state would have been able to enforce against the harmful conducts of its sister states had it been a sovereign unit. ${ }^{32}$ At this point, it becomes almost self-evident that the main concern of the Supreme Court was almost exclusively one of federalism. ${ }^{33}$ In other words, employing the doctrine of parens patriae, the Supreme Court ensured the states that the constitutional structure of the young federation supplied legal mechanisms to solve the conflicts emerging between the states, and therefore retaliatory responses ultimately, trade wars - were no longer necessary nor desirable. Third, in most of the earlier cases, the states had sought injunctive relief exclusively, and even when they had prayed for it in the context of antitrust, the courts had refused to grant compensatory remedies until the explicit authority was granted by the Congress.

\footnotetext{
${ }^{30}$ The states are believed to possess three groups of interests: sovereign interests referring to the interest of a state in maintaining the public order through enforcement of its laws; the quasi-sovereign interests referring to the interest of a state in protecting the health and well-being of its citizens; and proprietary interests referring to the interests of the state in protecting its properties from harm like any other legal or real person, see Richard P. leyoub, Theodore Eisenberg (1999), State Attorney General Actions, the Tobacco Litigation, and the Doctrine of Parens Patriae, Tulane Law Review, 74(5):1859-1883, at 1863.

${ }^{31}$ See e.g. Missouri v. Illinois 180 U.S. 208 (1901) on the discharging of sewage into the Des Plaines River; Kansas v. Colorado, 185 U.S. 125 (1902) on the diversion of waters from the Arkansas River by Colorado; Georgia v. Tennessee Copper Co., 206 U.S. 230 (1907) on the operation of a factory discharging noxious fumes into Georgia from across the state line; Pennsylvania v. West Virginia, 262 U.S. 553 (1923) on an export barrier caused by the statute requiring companies to supply natural gas to customers within the State before shipping out.

${ }^{32}$ See e.g. Kansas v. Colorado where the Court stated that "it was functioning as a surrogate for the kind of diplomatic action that independent States could take (absent a federal union) in settling similar conflicts", 185 U.S. 125 (1902), at 144; Missouri v. Illinois where the court found the state's concern about general health and safety of its population legitimate as it could have been able to address those concerns through "warfare and diplomacy" had it been independent, id., at 205.

${ }^{33}$ Malina, Blechman, supra note 25, at 209.
} 
Discovery of parens patriae by the Supreme Court as a doctrinal tool to overcome conflicts of externalities and trade restrictions between the states dates back to 1899 when Louisiana complained that quarantine regulations of Texas had placed a de facto embargo against the commerce originating from New Orleans. ${ }^{34}$ In this case, although acknowledging that the requirements of its original jurisdiction were not entirely satisfied, the Court nevertheless decided that, when their quasi-sovereign interests were bruised states were naturally entitled to be heard on the basis of parens patriae, reasoning that:

\begin{abstract}
'...the cause of action must be regarded not as involving any infringement of the powers of the State of Louisiana, or any special injury to her property, but as asserting that the State is entitled to seek relief in this way because the matters complained of affect the citizens at large...the State of Louisiana presents herself in the attitude of parens patriae, trustee, guardian or representative of all citizens. ${ }^{35}$
\end{abstract}

At this point, it becomes eminent that although having its background in English common law, the American version of the parens patriae has gone far beyond the Prerogative Regis both in terms of its function and meaning, since "as a quasi-sovereign, the state no longer seeks to protect a dependent class; rather, its interest lies in the protection of the entire partia." ${ }^{36}$ Nevertheless, besides expanding the boundaries of both its original jurisdiction and the doctrine of parens patriae, the Supreme Court also emphasised the natural limits of this new device stemming from the very rationale of federalism. Beginning with the first parens patriae case, the Court repeatedly underlined that, existence of state's quasi-sovereign interest in protecting the well-being of its citizens is a vital condition for a conflict to qualify as a parens patriae case. ${ }^{37}$ For instance, in Pennsylvania v. West Virginia, when analysing the effects of the export ban on the well-being of the citizens, the Court emphasised that:

'The private customers [of natural gas] in each State not only include most of the inhabitants of many urban communities but constitute a substantial portion of the State's population. Their health, comfort and welfare are seriously jeopardized by the threatened withdrawal of the

\footnotetext{
${ }^{34}$ Louisiana v. Texas 176 U.S. 1 (1899).

${ }^{35}$ Id., at 19 , emphasis added.

${ }^{36}$ Curtis, supra note 25 , at 908.

${ }^{37}$ Malina, Blechman, supra note 25, at 207.
} 
gas from the interstate stream. This is a matter of grave public concern in which the State, as the representative of the public, has an interest apart from that of the individuals affected. It is not merely a remote or ethical interest but one which is immediate and recognized by law. ${ }^{38}$

In other words, the concept of parens patriae as originally understood by the Supreme Court was strictly related to the quasi-sovereign interests of the states which were deemed independent of and beyond the interests of the individual citizens 'even when [they] relate to the same subject matter'. ${ }^{39}$ Therefore, the Court consistently denied the efforts of the states to extend the concept of parens patriae to include the conflicts where either the individual proprietary interests of the citizens or the states were at stake. For instance, in New Hampshire and New York v. Louisiana, the Court rejected the cases which were brought on behalf of the citizens in debt to the sister states on the ground that:

'There is no principle of international law which makes it the duty of one nation to assume the collection of the claims of its citizens against another nation, if the citizens themselves have ample means of redress without the intervention of their government... when [the citizen] can sue for himself, there is no necessity for power in his state to sue on his behalf. $^{, 40}$

Likewise, cases brought by the states as the asset owner on behalf of failing banks $^{41}$ and railroad companies ${ }^{42}$ were rejected under the reasoning of the Court that:

'[The] parens patriae principle does not go so far as to permit resort to our original jurisdiction in the name of the state but in reality for the benefit of particular individuals, albeit the state asserts an economic interest in the claims and declares their enforcement to be a matter of state policy. ${ }^{43}$

\footnotetext{
${ }^{38}$ Pennsylvania v. West Virginia, 262 U.S. 553 (1923), at 592.

${ }^{39}$ Georgia v. Tennessee Copper Co. at 237; Malina, Blechman, aupra note 25, at 205.

40108 U.S. 76 (1883), at 90-91.

${ }^{41}$ Oklahoma ex rel. Johnson v. Cook, 304 U.S. 387 (1938)

42 Kansas v. United States, 204 U.S. 331 (1907); Oklahoma v. Atchinson, Topeka \& Santa Fe Railway, 220 U.S. 277 (1911).

${ }_{3}^{3}$ Oklahoma ex rel. Johnson v. Cook, at 394.
} 
In a more recent case, the Supreme Court once again clarified the main element of a successful parens patriae action as the existence of a state interest apart from the interests of individuals which may relate to both the economical and physical well-being of a 'sufficiently substantial' segment of its population and which the state cannot be denied within the logic of the federal system. ${ }^{44}$

\section{Parens Patriae within the Context of Antitrust: Early Cases}

It was exactly the economic element of the concept of well-being which led to the expansion of the parens patriae doctrine to the domain of antitrust. However, the motivations behind the early antitrust cases still happened to be far away from the objectives of modern antitrust philosophy. First of all, those cases were brought against the harm caused to the economy of the state in general as a result of antitrust violations, and the consumers were not even mentioned. Second, the rationale of the Court when granting the remedies was neither deterrence against conspiracies nor redress to the customers, but the requirements of the federal union.

Perhaps it is more than apparent in Georgia v. Pennsylvania Railroad Co. ${ }^{45}$ which was brought against a price-fixing conspiracy among the railroad companies, and as a result of which travel rates in Georgia had become considerably higher than in other states. When accepting the case the Court reasoned that:

'Georgia as a representative of the public is complaining of a wrong, which if proven, limits the opportunities of her people, shackles her industries, retards her development, and relegates her to an inferior economic position among her sister States. These are matters of grave public concern in which Georgia has an interest apart from that of particular individuals who may be affected. Georgia's interest is not remote, it is immediate. ${ }^{46}$

As a result, the interest which the Court aimed to protect was not one of customers who were forced to pay higher prices for their train journeys, but it

\footnotetext{
${ }^{44}$ Alfred L. Snapp \& Son, Inc. V. Puerto Rico, 458 U.S. 592 (1982), at 607.

${ }^{45} 324$ U.S. 430 (1945).

${ }^{46}$ Id., at 451.
} 
was the interest of the state herself, or even the federation, in the prevention of trade barriers caused by price-fixing and price discrimination which deemed harmful to the prosperity and the welfare of the nation. ${ }^{47}$ Although the reasoning does not seem completely appropriate under modern antitrust philosophy, Georgia still deserves some merit as it was the first case where injunction was granted against an antitrust violation under the doctrine of parens patriae. As another interesting aspect, Georgia was the first case where compensation is sought solely on parens patriae grounds, which unfortunately was rejected on procedural grounds without substantive analysis. ${ }^{48}$

In Hawaii v. Standard Oil Co., ${ }^{49}$ the question of damages was brought before the court once again as in this case Hawaii sought damages as well as injunctive relief against the harm caused to the general economy of the State by a price-fixing conspiracy among the oil companies. In addressing the question, the Court engaged in a substantial analysis of the Clayton Act on the one hand, and the compensability of the damage to the general economy on the other. First of all, the Court distinguished Section 4 of the Clayton Act which requires the existence of injury to 'business or property' as the main condition for the award of damages, ${ }^{50}$ from Section 16 on injunctive relief which can be satisfied when 'threatened loss or damage' to any kind of interest exists. ${ }^{51}$ As the Court was certain that 'business or property' within the meaning of Clayton Act exclusively referred to 'commercial interests or enterprises', harm to the general economy of the state did not qualify to award of damages. ${ }^{52}$ Therefore, $^{2}$ under those circumstances the state could only sue for injunction under Section 16 of the Clayton Act which had a broader scope. In addition, the Court reasoned that:

"[T]he injury to the "general economy" as it is measured by the economists is no more than a reflection of injuries to the business or

\footnotetext{
${ }^{47}$ Susan Beth Farmer (1999), More Lessons form the Laboratories: Cy Pres Distributions in Parens Patriae Antitrust Actions Brought by State Attorneys General, Fordham Law Review, 68(2):361-406at 368-69.

${ }_{48}$ As the rates were approved by the Interstate Trade Commission, the Court rejected the claim for compensation following Keogh v. Chicago \& N.W.R. Co., 260 U.S. 156 (1922).

49405 U.S. 251 (1972).

5015 U.S.C.A \& 15.

${ }^{51} 15$ U.S.C.A § 26.

52 Hawaii v. Standard Oil Co., supra note 49, at 264.
} 
property of consumers, for which they may recover themselves under [Section] 4. ${ }^{, 53}$

In other words, as the consumers themselves were able to recover the damages they have suffered, there was no quasi-sovereign interest for the part of the State, and as a result, the State lacked standing to sue for damages under the doctrine of parens patriae.

Nearly two decades after Hawaii, states attempted to obtain damages by utilising the doctrine of parens patriae for the second time. . In this second attempt, California did not claim redress for its economy, rather, it was explicitly consumers on whose behalf compensation was sought. Therefore, the federal courts for the first time faced the question 'whether a state, as parens patriae, may sue and recover treble damages on behalf of its citizen-consumers for the injuries suffered by them'. ${ }^{54}$ The Court of Appeals observed that this question was quite different from that presented in Hawaii, where damages had been sought for the injury to the general economy of the state..$^{55}$ As the existence of a quasi-sovereign interest independent of the citizens had been the strongest pillar of the American parens patriae tradition, the Court reasoned that awarding damages 'would be a substantial departure' from the stare decisis. ${ }^{56}$ Acknowledging that obtaining redress on behalf of the citizens '[might] be a worthy State aim, ${ }^{57}$ nevertheless the Court did not find itself capable of providing such authority. Rather, the Court emphasised the necessity of legislative action by stating that:

'...[l]f the state is to be empowered to act in the fashion here sought we feel that authority must come not through judicial improvisation but by legislation and rule making, where careful consideration can be given to the conditions and procedures that will suffice to meet the many problems posed by one's assertion of power to deal with another's property and to commit him to actions taken in his behalf. ${ }^{, 58}$

\footnotetext{
${ }^{53} \mathrm{Id}$.

${ }^{54}$ The State of California v. Frito-Lay Inc., et al., 474 F.2d 774 (1973), at 775, cert. denied, 412 U.S. 908 (1973).

${ }^{55} \mathrm{Id}$.

${ }^{56} \mathrm{Id}$.

${ }^{57}$ Id at 777 .

${ }^{58} \mathrm{ld}$.
} 
Put simply, parens patriae as a concept developed solely for the purposes of federalism was neither a suitable device to be stretched to satisfy the objectives of consumer redress nor a clever enough political tool to overcome many problems likely to be brought by the usage of private enforcement mechanisms by the states for public purposes. Therefore, political action by the legislature was necessary to consider the appropriateness of the end which California sought. Congress responded quickly.

\section{Modern Parens Patriae: the HSR Act}

After almost two centuries since the passage of the American constitution Congress was considering changing the structure of federal antitrust enforcement substantially through adoption of a large package which inter alia proposed involvement of the State AGs to the federal picture as parens patriae. This time the main motivation behind the utilisation of the concept was not concerns of federalism or unity, however. Rather, evidence suggests that the legislature was more concerned about the effectiveness of the federal antitrust enforcement.

First of all, the bill coincided to a time where there was considerable criticism about the success of enforcement activities of the federal agencies in detecting and punishing violations effectively. ${ }^{59}$ Second, there was also serious concern about the functioning of private enforcement mechanisms, and particularly whether they had accomplished the goal of providing redress to consumers injured by the antitrust violations. According to the House of Representatives, the answer to this question was negative:

"The aggregate loss to "thousands or even millions of consumers" forced by antitrust conspiracies to pay excessive prices was presumed to be large, but the injury caused to any individual consumer was likely to be fairly small, even after trebling. Therefore, the Committee concluded that consumers were likely to have been harmed by antitrust violations but had little prospect of obtaining effective redress in the form of damages. The antitrust laws would

\footnotetext{
${ }^{59}$ Particularly, the Antitrust Bar Association has published a report on 1969 which declared common concern of the Association on the activities of the Federal Trade Commission and whether the Commission was performing its duties as effectively as it should. The Congress has taken the Report seriously and urged the Commission to follow the recommendations of the Report, see William E. Kovacic (1988), Congress and the Federal Trade Commission, Antitrust Law Journal, 57:869-905, at 874-875.
} 
lose their deterrent power if relief was unavailable for those harmed, and if the violators could retain their illegal gain. ${ }^{60}$

It was particularly so, due to the strict conditions of class actions as a result of which the availability of redress to a mass became only coincidental at best. ${ }^{61}$ Therefore, arguably, there was consensus on at least the desirability of some improvement to both the public and the private faces of federal antitrust enforcement. Congress aimed to address two aspects of the problem in a single solution. Recognising the parens patriae position of the State AGs, the HSR Act ${ }^{62}$ gave them the authority to seek injunctions and treble damages on behalf of their citizens hurt by the violations of federal antitrust law. Thus, the State AGs became the public enforcers of federal antitrust laws utilising private enforcement methods. At the same time, with the passage of another Bill, State AGs were also provided additional financial resources from the federal budget to perform their new duties. ${ }^{63}$

As a result, the substance of parens patriae evolved once again, and the doctrine became a private enforcement mechanism of federal antitrust laws for public purposes. However, despite this significant transformation, the strongest idea behind the concept - the interest of a sovereign in the wellbeing of its citizens - has remained intact since its invention by the common law. After all, Congress explained its political choice by '[the] primary duty of the State... to protect the health and welfare of its citizens' ${ }^{64}$

\section{E. Strength of Parens Patriae: Class Actions Compared}

One of the considerations of Congress in foreseeing the mechanism of parens patriae was to provide effective redress to consumers who were unlikely to press their claims in the courts especially when the expected individual compensation was lower than the cost of litigation. One may wonder about the potential extra benefit expected from parens patriae actions in this context, when other methods of mass compensation already existed.

\footnotetext{
${ }^{60}$ House of Representatives Report No.94-499, at 4 (1976).

61 The drawbacks of class actions are discussed in detail in the following section, see infra pp. 18-23.

62 Hart-Scott-Rodino Antitrust Improvements Act of 1976, Pub.L. 94-435, 15 U.S.C.A § 15c-h, $18 \mathrm{a}, 66$.

${ }^{63}$ Crime Control Act of 1976, Pub.L. 94-503, Oct. 15, 1976, 90 Stat. 2407.

${ }^{64}$ House of Representatives Report No.49-499 at 5 (1976), emphasis added.
} 
After all, class actions as a general mechanism to provide compensation to the members of a mass who suffer from the same wrong had been recognised and applied within the context of antitrust long before the passage of the HSR Act. ${ }^{65}$ Besides, in a number of occasions the courts had appointed the State AGs as the class representatives. ${ }^{66}$ Therefore, there was already an alternative mechanism to provide compensation to the consumers who were unlikely to pursue litigation individually. However, class actions do not constitute a perfect substitute to the parens patriae actions due to the strict procedural conditions required by the federal law, and significant principalagent problems involved. ${ }^{67}$

In class actions federal courts are required to address three questions consecutively: first, whether the group can be certified as a class; second, whether the liability of the defendant and the amount of damages is proven; and third, how the compensation will be distributed. In all stages there are strong procedural hurdles to be cleared.

As preconditions of class certification, questions of law or fact common to all members of the class should predominate over individual questions, ${ }^{68}$ class action must be 'manageable' and superior to other methods of litigation, ${ }^{69}$ and since the judgment has the res judicata power for all class members unless they opt-out, ${ }^{70}$ all potential members should be identified and given notice. ${ }^{71}$ First of all, in the context of antitrust it proves very hard for a group to fulfil the requirement of commonality, since as a requirement of the Clayton Act, all members of the class become obliged to prove that the damages in fact have occurred before proving the exact amount of compensation required. ${ }^{72}$

\footnotetext{
${ }^{65}$ Like most of the foundations of modern American law, class actions originate from England: "The class action originated in the English courts of chancery with the 'bill of peace'. A creature of equity, the bill of peace allowed a representative of a group of similarly injured persons to bring suit on behalf of absent class members as well as herself.", see Natalie A. DeJarlais (1987), The Consumer Trust Fund: A Cy Pres Solution to Undistributed Funds in Consumer Class Actions, 38(4):729-767, at 732.

${ }^{66}$ In particular West Virginia v. Charles Pfizer \& Co., 440 F.2d 1079 (2d Cir. 1971) where the Court have allowed a litigation scheme similar to parens patriae cases including the method of distribution of damages, see Owens, supra note 28 , at $159-60$.

${ }^{67}$ Farmer, supra note 47 , at 389.

${ }^{68}$ Federal Rules of Civil Procedure 23(b)(3)

${ }^{69}$ Id.

70 Patricia J. O'Donnell-Gaynor (1982), The Antitrust Improvements Act of 1976, Parens Patriae Act: Paper Tiger or Sleeping Giant, Cleveland State Law Review, 31(1):107-143, at 127.

${ }^{71}$ Federal Rules of Civil Procedure 23(c)(2)(B).

${ }^{72}$ Curtis, supra note 25 , at 912.
} 
Second, as a result of the manageability requirement, class actions fall short of providing redress to as large a number of consumers as the parens patriae actions do. In the analysis of manageability, the courts generally compare the relative costs of individual notice to members of the class and distribution of damages - if granted - to the expected individual compensation to the members. ${ }^{73}$ As identifying all potential members of a class and giving notice to them becomes extremely costly, cases involving long-lasting, multi-state conspiracies generally fall on procedural grounds. For instance, antitrust class actions brought on behalf of gasoline purchasers in New Jersey, Pennsylvania and Delaware were held unmanageable and rejected. ${ }^{74}$ Likewise, in Eisen, a class action brought on behalf of some six million odd-lot traders on New York Stock Exchange as a result of antitrust and securities violations held unmanageable as the individual damage suffered (which was $\$ 1.30$ per class member) was 'so low as to be negligible'. ${ }^{75}$ As a response to this case, it was stated in the Congress that:

'The practical effect of Eisen is to eliminate the Rule 23 class action as a feasible means for recovery by a large class of individuals each of whom has sustained relatively minor damages. In situations where the costs of giving notice to the class are much greater than any individual class member's stake in the outcome of the action, it is unlikely that any suit will be brought. The person who deals in certain types of consumer goods, where each transaction may involve only a few dollars, can now fix the prices, relatively free from the fear of substantial treble damage actions. ${ }^{, 76}$

Even if the procedural hurdles are cleared and the class is successfully certified in any given case, substantive analysis and distribution of damages in a class action is just as difficult. In the context of class actions, proof of damages on an aggregate basis is not sufficient, but verification of the exact

\footnotetext{
${ }^{73}$ O'Donnell-Gaynor, supra note 70, at 127-28; Nyal D. Deems (1974), The Cy Pres Solution to the Damage Distribution Problems of Mass Class Actions, Georgia Law Review, 9(4):893-929 at 901.

${ }_{75}^{74}$ City of Philadelphia v. American Oil Co., 53 F.R.D. 45 (D.N.J. 1971).

${ }^{75}$ Eisen v. Carlisle \& Jacquelin, 52 F.R.D. 253 (S.D.N.Y. 1971), rev'd, 479 F.2d 1005(2d Cir. 1973), at 1017, vacated, 417 U.S. 156 (1974); emphasis added.

${ }^{76}$ Hearings on House of Representatives 38 and 2850 before the monopolies and commercial law subcommittee of the house committee on the judiciary, $94^{\text {th }}$ Congress, $1^{\text {st }}$ session 16 (1975) statement of James T. Halverson. Some commentators believe that the recognition of parens patriae was in part a direct response to Eisen: "having come to a dead end in the Courts, the search for a procedure to vindicate small consumer claims in antitrust suits moved to the Congress", see Milton Handler, Michael D. Blechman (1976), Antitrust and the Consumer Interest: The Fallacy of Parens Patriae and a Suggested New Approach, Yale Law Journal, 85(5):626-676, at 632.
} 
amount is required. ${ }^{77}$ When it comes to the distribution of damages, the position of the federal policy is less clear. In Eisen III, as the class had been held unmanageable inter alia on the grounds of difficulty of damage distribution to some six million members, on remand from the Court of Appeals the District Court adopted the method of 'fluid recovery'. This method suggested creation of a fund equivalent to the amount of unclaimed damages through reducing the price of odd-lots in a portion approved by the Court until the fund is depleted. ${ }^{78}$ As a result, the fund would benefit future odd-lot traders rather than the traders individually injured by the conspiracy. ${ }^{79}$ The Court of Appeals rejected this proposition on due process grounds, and the Supreme Court vacated the judgment without commenting on this issue. ${ }^{80}$ Therefore, to date, there has been no clear guidance from the Supreme Court whether fluid recovery is possible in the context of class actions or individual distribution is required. Although some courts have attempted to relax the conditions of damage distribution to class members, the federal policy seems to be in favour of individual distribution. ${ }^{81}$

In parens patriae actions, on the other hand, there is no formal certification phase. Although it is required that consumers on whose behalf the case was brought should be given notice for due process concerns as the judgement has res judicata effect on any future claims, less costly means of notification such as notification through publication are allowed. ${ }^{82}$ In price-fixing cases, proof of aggregate damages through statistical or sampling methods is allowed, and proof of the exact amount is not strictly necessary. ${ }^{83}$ Besides, individual distribution of damages is not the only way: damages can be

\footnotetext{
${ }^{77}$ Although some cases, such as Nasdaq Market Makers Antitrust Litigation, 169 F.R.D. 493 (S.D.N.Y.1996), have allowed the computation of damages on an aggregate basis, those cases seem to be the exception rather than the rule. See Stephen Calkins (1997), An Enforcement Official's Reflections on Antitrust Class Actions, Arizona Law Review, 39(2): 413-451, at 418.

${ }^{78}$ Eisen v. Carlisle \& Jacquelin, 52 FRD 253 (S.D.N.Y. 1971), at 265.

${ }^{79} \mathrm{ld}$.

${ }^{80}$ Eisen v. Carlisle \& Jacquelin, 417 U.S. 156 (1974); Nyal D. Deems, supra note 73, at 910-12.

${ }^{81}$ The stance of the individual courts seems to vary depending on their political belief whether deterrence or individual compensation should be the main function of the class actions, see Stephen Calkins, at 420-27; Nyal D. Deems, id., 917-920.

82 15 U.S.C.A § $15 c(2)(b)$.

${ }^{83} 15$ U.S.C.A § 15d. Aggregate computation of damages is not entirely new to the US law and had been employed within the context of tort law before with the consideration: "Where the tort itself is of such a nature as to preclude the ascertainment of the amount of damages with certainty it would be a perversion of fundamental principles of justice to deny all relief to the injured person, and thereby relieve the wrongdoer from making any amend for his acts...[T]he risk of uncertainty should be thrown upon the wrongdoer instead of upon the injured party", see Story Parchment Co. v. Parterson Parchment Paper Co., 282 U.S. 555 (1931), at 563.
} 
distributed in any way which is approved by the court or can even be deposited to the state treasury as a civil penalty. ${ }^{84}$

Another interesting feature and advantage of the parens patriae actions stems from the duty of cooperation of the federal government. Federal law holds the Attorney General of the United States (the head of the Department of Justice) responsible for communicating with the State AGs when he is investigating a violation and has reasons to believe that the State AGs might be interested in bringing a parens patriae action against the same conduct. $^{85}$ Besides, collection of evidence is also easier for the State AGs since upon request, the Department of Justice is also required to share any investigative files and other materials with them to the extent permitted by law. ${ }^{86}$

Hence, by recognising parens patriae, Congress has created an entirely new device which uses private enforcement channels but has various advantages compared to classic private enforcement channels. Although historical evidence - particularly the remarks to the House of Representatives - seem to underline that the objectives of deterrence and individual redress were given equal magnitude, it appears that the public enforcement motivations behind the Act were stronger than those of private redress, particularly when the provisions allowing the State AGs to keep the compensation as a civil penalty is considered. ${ }^{87}$ Therefore, parens patriae is not only a stronger device than class action, but it also serves to different purposes. On the other hand, if the only concern of Congress had been the detrimental effects of the strict procedural conditions of class actions on the private enforcement of federal antitrust law, it would have simply relaxed those conditions. Thus, the objective of Congress by recognising parens patriae was not merely creating

\footnotetext{
${ }^{84} 15$ U.S.C.A $\S 15$ e; distribution of damages is discussed in the following section at length, see infra pp. 23-27.

8515 U.S.C.A. $\S 15 f(a)$.

8615 U.S.C.A. § $15 \mathrm{f}(\mathrm{b})$. The law permits the reach of the State AGs almost any kind of documents, except for grand jury materials where a "particularised need" must be shown under the Federal Rules of Criminal Procedure. See Michael Martin, Disclosure of Grand Jury Materials in Parens Patriae Actions, 81 Columbia Law Review, 411 1981; U.S. v. Colonial Chevrolet Corp., 629 F.2d 943 (1980), cert. denied 450 U.S. 913; In re Grand Jury Investigation of Cuisinarts, Inc., 665 F.2d 24 (1981), cert. denied 406 U.S. 1068; Illinois v. Abbot \& Associates, Inc., 460 U.S. 557 (1983); In re Grand Jury Proceedings, 712 F.2d 973 (1983).

87 Some commentators objected the HSR Act arguing that pursuance of public policy considerations without sufficient procedural checks render the Act unconstitutional, see Malina, Blechman, supra note 25, at 216.
} 
a "super class action"88 relieved from procedural safeguards, but it was innovating an entirely new device contributing both to the private and public face of the enforcement of federal antitrust laws.

Another drawback of class actions is the serious principal-agent problems involved. ${ }^{89}$ In an average class action, monitoring of the attorney(s) by the clients is highly unlikely as they do not even meet unless it is vital for the purposes of litigation. ${ }^{90}$ Besides, the incentive of an individual client to monitor his attorney is relatively small in correlation with the amount of expected individual compensation at the end of the litigation. ${ }^{91}$ On the other hand, the attorney and the client have largely different stakes involved. Whereas the client hopes to be awarded compensation at the end of the litigation, it is in the interest of the attorney to secure his fee as high as possible particularly through bargaining with the defendant. ${ }^{92}$ Therefore, it is likely that the attorney will choose to make a 'sweetheart deal' with the defendant in return of a high fee. ${ }^{93}$ Principal-agent problems become less serious in the context of parens patriae actions due to the political position of the State AGs and their duties of public nature. First of all, potentially it should be easier to monitor the office of the State AGs as they are politically accountable to the public. ${ }^{94}$ Second, the State AGs represent the public in general, and their purpose of pursuing antitrust cases is not the expectation of an attorney's fee but reputation and possibility of re-election at the end of their term. Therefore, in the context of parens patriae cases, asymmetric stake problems are not expected to arise as the interests of State AGs coincide with those of consumers. ${ }^{95}$ Ultimately, the State AG was seen as 'an effective and ideal spokesman for the public in antitrust cases', by the Congress and given authority to pursue antitrust

\footnotetext{
${ }^{88}$ See contra Eustace A. Oliff III (1976), Parens Patriae Antitrust Actions for Treble Damages, Harvard Journal on Legislation, 14(2):328-357, at 334 .

89 John C. Coffee (1986-1987), Jr., Rethinking The Class Action: A Policy Primer on Reform, Indiana Law Journal 62(3): 625-664..

${ }_{90}$ Id., at 629; Farmer, supra note 47 , at 389.

${ }^{91}$ Farmer, Id.

${ }^{92}$ Coffee, Jr, supra note 89, at 635-36; Farmer, id., at 390.

${ }^{93}$ Farmer, Id.

94 Edward Brunet (1999), Improving Class Action Efficiency by Expanded Use of Parens Patriae Suits and Intervention, Tulane Law Review, 74(5):1919-1939, at 1931.

${ }_{95}$ Id., at 1936. Although it can be argued that capture by the local industrial interests is possible, and unfair settlements can arise in such situations, it is more logical that the State AGs would not go to the court in the first hand in such situations rather than closing the deal for cheap.
} 
cases, because '...[h]e is normally an elected and accountable and responsible public officer whose duty is to promote the public interest'. ${ }^{96}$

\section{F. Public Nature of Parens Patriae: Distribution of Damages}

The parens patriae mechanism, as foreseen by the federal law, does not only involve more lax procedural conditions, but also, courts and the State AGs were given considerable discretion in the distribution of damages.

In a large number of antitrust actions for treble damages, distribution of damages directly to the injured individuals becomes impossible or prohibitively costly. Particularly in the context of multi-state long-lasting violations identifying the individuals who were injured and distributing the damages directly to them may outweigh the amount of secured compensation. ${ }^{97}$ Second, when the subject of violation is an item of relatively low value which is consumed regularly, the consumers may not always step forward to claim their share of damages either because the expected individual amount of compensation is relatively low or they have not kept any form of evidence such as receipts to prove that they belong to the injured group on whose behalf the compensation is secured. ${ }^{98}$ As a result, if the method of direct distribution to individual consumers is followed, whole or part of the damage fund remains undistributed.

In cases where the problem of damage distribution arises, the courts and the State AGs generally face five options to distribute the damage fund: first, returning undistributed damages to the defendant; second, in cases where only a portion of the damages remain unclaimed, distributing the rest of the fund to the consumers who claimed damages; third, distributing damages through fluid recovery mechanisms such as coupons or future price reductions; fourth, depositing the damage to the state treasury as a civil penalty; and five, applying 'cy pres' distribution mechanisms. ${ }^{99}$

\footnotetext{
${ }^{96}$ House of Representatives Report No.94-499, $94^{\text {th }}$ Cong.,2d Sess (1975) reprinted in 1976 U.S.C.C.A.N. 2575, see Stephen Calkins at 434.

${ }_{97}$ Farmer, supra note 47, at 391; Stewart R. Shepherd (1972), Damage Distribution in Class Actions: The Cy Pres Remedy, University of Chicago Law Review, 39(3):448-465, at 451; DeJarlais, supra note 47, at 730.

${ }^{98}$ Farmer, ld.

${ }^{99}$ Farmer, id., at. 394; Shepherd, id., at 453, 457, 461-62; DeJarlais, id., at 731.
} 
Of all these options, returning the damages to the defendants is the least desirable as it is contrary to both deterrence and redress considerations behind parens patriae actions. ${ }^{100}$ Distributing the rest of the compensation to consumers who have claimed damages triggers windfall effects, and proves to be inefficient as it causes unjust enrichment for some of the injured consumers at the expense of the others. ${ }^{101}$ Distributing damages through fluid recovery mechanisms such as coupons or future price reductions benefits future consumers rather than the ones injured by the past conduct. ${ }^{102}$ Besides, such techniques - particularly price reductions - require monitoring and enforcement mechanisms to make sure that the producer is following the conditions of relief without reducing the quality of the good. ${ }^{103}$ In addition, such mechanisms are likely to cause competitive advantage to the conspirators in the market as a result of artificially low prices. ${ }^{104}$ Depositing damages to the state treasury as a civil penalty leaves the objective of redress to injured consumers entirely unfulfilled. Although hypothetically contribution to public services is expected as a result of the raise of revenue, this would benefit the citizens in total and not directly the injured ones. ${ }^{105}$ Nevertheless, since the 1990s it seems to have become a standard part of the settlements that the undistributed part of the fund or, in some cases, the whole fund should be escheated to the state to be used solely for the purposes of antitrust enforcement. ${ }^{106}$ Compared to escheating the fund to the state treasury without any specific condition, this solution arguably follows the objectives of parens patriae more closely, as it raises the resources of the State AGs to the benefit of the victims of future antitrust violations. In fact, it has been argued before the Antitrust Modernization Commission that to overcome the financial problems that the State AGs are facing, federal laws should be amended to give them formal authority to keep a part of the

\footnotetext{
${ }^{100}$ Oliff III, supra note 88, at 333; Farmer, id., at 394; Shepherd, id., at 451; DeJarlais, id., at 732-733.

101 Oliff III, id., at 333; Farmer, id., at 394; Shepherd, id., at 451; DeJarlais, id., at 732-733.

102 Oliff III, id.; Farmer, id.; Shepherd, id., at 453; DeJarlais, id.

103 Oliff III, id.; Farmer, id.; Shepherd, id., at 461-62; DeJarlais, id.

104 Oliff III, id.; Farmer, id.; Shepherd, id., at 457; DeJarlais, id.

105 Oliff III, id.; Farmer, id.; Shepherd id.; DeJarlais, id.

106 See e.g. Missouri v. American Cyanamid, Not Reported in F.Supp., 1997 WL 129408 (W.D.Mo.), 1997-1 Trade Cases P 71,712; New York v. Primestar Partners, Not Reported in F.Supp., 1993 WL 527984 (S.D.N.Y.), 1993-2 Trade Cases P 70,404; New York v. Nintendo of Am. Inc., 775 F.Supp. 676, 1991-2 Trade Cases P 69,614; Re Clozopine Antitrust Litigation MDL 874 (90 C. 6412 ; 91 C. 2431) (N.D. III .) (HDL).
} 
damages they secure in parens patriae cases. ${ }^{107}$ However, even if it may contribute to the quality of antitrust enforcement and thereby maintain the public rationale behind parens patriae actions, it is obvious that this method does not provide any relief to the consumers injured by the particular antitrust violation.

Among all, cy pres distributions prove to be the most consumer-friendly, and therefore most likely to be approved by the courts. Literally, the phrase 'cy pres' originates from the Norman French expression 'cy pres comme possible' which means as nearly as possible. ${ }^{108}$ As a legal doctrine, originally cy pres has been applied in the context of the testamentary charitable gifts which can not be carried out as the testator intended because of illegality, impossibility or any other reason. ${ }^{109}$ In such cases, applying the principle of $c y$ pres, courts place the funds to the closest possible alternative to the original intention of the testator. ${ }^{110}$

In the context of parens patriae actions, when distribution of whole or part of the damage fund becomes impossible or prohibitively costly for any of the above reasons, the State AGs and the courts employ cy pres mechanisms to put the damage fund to the next possible use which benefits the consumers injured by the particular conspiracy indirectly. In such cases, generally the fund is allocated to private or public charities providing services to the injured consumer group with a purpose closely related to the subject matter of the particular conspiracy.

The milk antitrust investigation conducted by the State of New York best illustrates the functioning of $c y$ pres mechanism in practice. ${ }^{111}$ The subject matter of that case was a price-fixing conspiracy in the market for retail milk which was believed to last for approximately fourteen years in eleven different

\footnotetext{
${ }^{107}$ Remarks by Prof. Harry First before the Antitrust Modernization Commission, Transcripts of Public Hearing on Allocation of Antitrust Enforcement between the States and the Federal Government, available at http://www.amc.gov/commission hearings/pdf/051026 State Enforc Transcript reform .pdf at 108.

${ }_{108}$ DeJarlais, supra note 65, at 730 citing E. Fisch, The Cy Pres Doctrine in the United States $\S 1000$ at 1 (1950).

109 DeJarlais, id.; Deems, supra note 73, at 894; Shepherd, supra note 97, at 452; Farmer, supra note 47, at 364.

${ }^{110}$ DeJarlais, id.; Deems, id.; Shepherd, id.; Farmer, id.

${ }^{111}$ New York v. Dairylea Cooperative Inc., Not Reported in F.Supp., 1985 WL 1825 (S.D.N.Y.), 1985-2 Trade Cases P 66,675.
} 
counties of New York. As a result of settlement negotiations, New York secured $\$ 6.1$ million for compensation of the injured citizens. However, since milk is a product of a relatively low price which is consumed regularly, consumers were not expected to step forward to prove and claim damages. Moreover, it was unfeasible for the State AG to identify all consumers affected by the price-fixing for the same reason. Whereas individual damage to each household was around $\$ 1.5$ and to each resident $\$ 0.50$, the Court calculated the cost of individual distribution as approximately $\$ 2.5$ million, nearly half of the secured compensation. ${ }^{112}$ Therefore, it was decided that the whole fund be distributed through cy pres mechanisms to the schools in the counties affected by the price-fixing to be used solely for nutrition purposes. ${ }^{113}$

However, cy pres mechanisms are not equal in value to direct distribution, and therefore cannot be used as an escape from the complexities of damage distribution. ${ }^{114}$ Considering the consumer redress rationale behind parens patriae actions, direct distribution still prevails where it is feasible. For instance, in a case involving price-fixing between automobile dealers, direct distribution was preferred since an average person keeps some kind of proof of the purchase of an automobile, and in such cases the individual amount of compensation was considered to be sufficient to give the consumers incentives to claim their share of the damage fund. ${ }^{115}$ In another case involving price-fixing in the domestic air transportation market, direct distribution was preferred as every individual consumer was identifiable through the records of airline companies involved. ${ }^{116}$

In summary, in each case a cost and benefit analysis is performed when deciding on the most effective method of damage distribution. Such analysis focuses on the expected individual benefit to the consumers who were injured by the particular conspiracy, and the cost of distribution method. In some cases it becomes necessary to create more innovative methods to provide

\footnotetext{
${ }^{112} \mathrm{Id}$.

${ }_{113}^{113}$ Id.

114 The courts approve cy pres methods as long as they prove to be "fair, reasonable and adequate" within the context of a particular case, see infra pp. 27-29.

115 In re Mid-Atlantic Toyota Antitrust Litigation, 605 F.Supp. 440, 1985-1 Trade Cases P 66,417.

${ }_{116}$ In Re Domestic Air Transportation Antitrust Litigation, 148 F.R.D. 297, 61 USLW 2610, 1993-1 Trade Cases P 70,165 .
} 
best possible value for the consumers with the least possible cost. What is certain is that distribution of damages to a mass is a costly activity and it requires a high level specialisation. Arguably, it also involves a political decision regarding to the most effective method of damage distribution in each case. That seems to be the reason why the cy pres methods have been recognised in the field of parens patriae cases when their availability is still uncertain in class actions. In other words, as a political actor with accountability to the public, State AG has seemed both to Congress and the federal courts more likely to enshrine the benefit of citizen-consumers than private attorneys in such political decisions.

\section{G. Settlements: Control by the Courts}

As explained so far, parens patriae actions involve relatively lax procedural safeguards, and the State AGs possess considerable discretion in all phases of litigation, particularly so in determination of damages and the necessary injunctive remedies, since most cases end with settlements rather than final judgements. Those settlements are subject to the control of the federal courts. However, the control exercised by the federal courts appears to be rather limited, and therefore, the arguably political choices of the State AGs and the bargaining they have conducted against the plaintiff still proves to influence the outcome of the case to a large extent.

Although federal law requires approval of settlements in parens patriae actions by federal courts, it is silent when it comes to the conditions which the courts should follow when approving such settlements. ${ }^{117}$ As a solution, federal courts apply the conditions developed within the context of class actions by analogy when reviewing parens patriae settlements. ${ }^{118}$ Those conditions require the settlements to be 'fair, reasonable, and adequate' in order to be approved by the courts. ${ }^{119}$

\footnotetext{
11715 U.S.C.A. § $15 \mathrm{c}(\mathrm{c})$.

118 See New York v. Salton, Inc. 265 F.Supp.2d 310 (S.D.N.Y. 2003), at 313, emphasis added. As a general overview of the dynamics of court control on settlements see Lloyd C. Anderson (1983), The Approval and Interpretation of Consent Decrees in Civil Rights Class Action Litigation, University of Illinois Law Review 579: 579632. Lloyd C. Anderson (1996), United States v. Microsoft, Antitrust Consent Decrees, and the Need for a Proper Scope of Judicial Review, Antitrust Law Journal 65(1): 1-40.

${ }^{119}$ New York v. Salton, id.
} 
The condition of fairness focuses mainly on the negotiation process behind the settlement, and questions 'whether the settlement is resulted from good faith and arms-length bargaining between experienced counsel'. ${ }^{120}$ In such analysis, the possibility of collusion between the parties is given key importance to prevent 'sweetheart deals' to the detriment of consumers. ${ }^{121}$

Reasonableness and adequacy of the settlement, on the other hand, indicate a comparison between the benefit secured for the consumer as a result of settlement and the expected potential benefit from litigation in the court leading to a final judgment. When deciding whether the settlement is reasonable and adequate, federal courts consider 'the relative strength of the plaintiff's case on the merits, the existence of any difficulties of proof or strong defenses the plaintiffs are likely to encounter if the case goes to trial, the anticipated duration and expense of litigation, and the likelihood of recovery on a litigated judgment ${ }^{122}$ to make sure that settlement in any particular case produces the best outcome for the consumer and has strong justifications in terms of economics of litigation. The degree of opposition and the arguments of those opposing are also taken into account to make sure that consumers can come forward with their own opinions to protect their own interests when they believe that the State AGs have failed to do so. ${ }^{123}$

All of the elements considered by the courts in approval of settlements explained so far aim to protect the interests of consumers and prevent underenforcement as a result of collusion between the two sides of conflict. One should not be surprised by this, however, since these conditions have been imported from the context of class actions which involve strong principalagent problems. ${ }^{124}$ The only factor which the courts take into consideration which could bar over-enforcement is 'the solvency of the defendants'. ${ }^{125}$ In other words, so long as the defendants do not become bankrupted and as a result, the possibility of compensation to the consumers does not vanish

\footnotetext{
${ }^{120}$ New York v. Salton, id; State of New York v. Nintendo of America, Inc., supra note 106, at 680.

121 See e.g. New York v. Salton, id; State of New York by Vacco v. Reebok Intern. Ltd., 903 F.Supp. 532 (S.D.N.Y. 1995); In re Montgomery County Real Estate Antitrust Litigation, 83 F.R.D. 305 (D.C.Md. 1979).

122 New York v. Salton, id.

${ }^{123} \mathrm{ld}$.

124 See supra p.27.

${ }^{125}$ New York v. Salton, at 313.
} 
altogether, it is for the business to protect their own interests through bargaining and negotiation.

In summary, judicial review of settlements in parens patriae actions do not involve any substantive analysis, such as the proportionality of the injunctive and compensatory remedies, as in such review the courts rely on the requirements which were developed within the context of class actions to prevent under-enforcement. As a result, the outcome of the parens patriae actions depends to a large extent on the discretion of the State AGs and their relative strength in the negotiation process as long as the other party does not end up in bankruptcy due to the remedies granted.

\section{H. Limitations of Parens Patriae Actions}

Although State AGs enjoy considerable discretion in antitrust enforcement within the context of parens patriae, their ability to manoeuvre is subject to some restrictions imposed by federal law. First of all, following the modern antitrust philosophy which started to develop in the US in late 1970 s, ${ }^{126}$ federal law allows initiation of parens patriae actions only on behalf of natural persons. $^{127}$ In other words, State AGs can only resort to parens patriae actions to protect the interests of consumers, and the injury to the competitors within the state cannot be claimed through parens patriae actions. Second, parens patriae actions for treble damages are available only against violations of the Sherman Act, but not the other federal antitrust statutes. ${ }^{128}$

Second, in line with the authentic requirement of the existence of a 'quasisovereign interest' in parens patriae actions, the state cannot bring such action to protect its proprietary interests. When an antitrust violation causes injury to the state itself which is in the position of a consumer in a particular case, the state is required to follow the usual patterns of private action under

\footnotetext{
${ }^{126}$ See e.g. William J. Baer, David A. Balto (1999), The Politics of Federal Antitrust Enforcement, Harvard Journal of Law and Public Policy 23(1):113-132; William E. Kovacic (1989), The Antitrust Paradox Revisited: Robert Bork and the Transformation of Modern Antitrust Policy, Wayne Law Review 36(4)1413-1472; William E. Kovacic, Carl Shapiro (2000), Antitrust Policy: A Century of Economic and Legal Thinking, The Journal of Economic Perspectives, 14(1): $43-60$.

12715 U.S.C.A. $\$ 15(c)(1)$.

${ }^{128}$ Id. However, the State may plead for the injunction of other types of antitrust violations under the classical parens patriae doctrine. State AGs are very active in federal merger cases for example.
} 
the Clayton Act $\S 4$ and $\S 16$, and it cannot rely on the more advantageous procedure of parens patriae. $^{129}$

Third, and perhaps most interesting due to the political considerations involved and practical complexities caused, parens patriae actions - like any other types of private action under federal law - cannot be brought on behalf of indirect purchasers. In 1968, just after the passage of the HSR Act, the Supreme Court decided in Hanover Shoe ${ }^{130}$ that passing-on of damages cannot be used as a defense in the context of treble damages actions for antitrust violations. This case had been brought by a shoe manufacturer against a machine producer who allegedly monopolized the shoe machinery industry and caused injury to the shoe manufacturer by refusing to sell machines and supplying under lease agreements only. The machine producer argued that he should not be held liable for damages, as the machine producer passed the damages on to his consumers. The Supreme Court disagreed mainly for two reasons. First of all, the Court considered probable impacts of the passing-on defence on the judicial economy. As 'a wide range of factors influence a company's pricing policies', ${ }^{131}$ extra complicated economic evidence and analysis would be required to prove that the illegal overcharge actually was passed-on to the consumers, and such passing-on did not cause any significant decline in the total sales of the plaintiff. ${ }^{132}$ The second concern of the Court were the potential effects of the passing-on defence on the deterrent function of private actions. According to the Court, the actual effect of the passing-on defence would be to leave the final consumers as the only likely group to pursue private actions. As the final consumers did not have sufficient incentives to do so, federal antitrust laws would lose their deterrent effect with the recognition of the passing-on defence. $^{133}$

\footnotetext{
129 Georgia v. Evans, 316 U.S. 159 (1942); recognising the antitrust standing of a State when her proprietary interests are injured. For the scope of State's standing see Bobbee Musgrave (1976), Case Note: Antitrust- Standing (Florida ex rel. Shevin v. Exxon Corp., 526 F.2d 266 ( $5^{\text {th }}$ Cir. 1976), Southern Illinois University Law Journal 1(3): 527-537.

${ }^{130}$ Hanover Shoe, Inc. v. United Shoe Machinery Corp., 392 U.S. 481 (1968).

131 Id., at 492.

132 Id., at 493

${ }^{133}$ Id., at 494.
} 
A decade later, in Illinois Brick, ${ }^{134}$ the State of Illinois and local government entities sued brick manufacturers who stood two levels above them in the production chain for illegal overcharges caused by a price-fixing conspiracy. Therefore, the Court faced the question whether plaintiffs should be allowed to claim the overcharge passed onto them through production chain using passing-on arguments offensively. The Court first reasoned that; 'whatever rule is to be adopted regarding pass-on in antitrust damages actions, it must apply equally to plaintiffs and defendants' ${ }^{135}$ In other words, if the plaintiff was granted the opportunity to invoke passing-on offensively to claim damages, the defendant should be able to rely on the same argument defensively to refuse the claims for damages. Thus, the Court had to make a political choice either to overrule Hanover Shoe or to close the door to private actions by indirect purchasers. Largely due to the potential danger of multiple recoveries, ${ }^{136}$ the Court decided to choose the second alternative. According to the Court, if the first alternative was followed, federal courts would have to distribute the damages among all potential plaintiffs to prevent the danger of multiple recoveries, and the judicial mechanism could simply not shoulder such a burden:

'Permitting the use of pass-on theories under $\S 4$
essentially would transform treble-damages actions into
massive efforts to apportion the recovery among all
potential plaintiffs that could have absorbed part of the
overcharge - from direct purchasers to middleman to
ultimate consumers.' ${ }^{, 137}$

As most of the conspiracies generally occur among the manufacturers high above the final consumers in the production chain, the general belief was that as a result of Illinois Brick, private actions by final consumers and ultimately parens patriae mechanism would become entirely redundant. ${ }^{138}$ Therefore, the response of the states to the judgment of the Supreme Court was rather

\footnotetext{
${ }^{134}$ Illinois Brick Company et al. v. State of Illinois, 431 U.S. 720(1977).

${ }^{135}$ Id., at 728.

${ }^{136}$ Id., at 730

${ }^{137}$ Id., at 737.

${ }_{138}$ Oliff III, supra note 88, at 344, 350; O'Donnell-Gaynor, supra note 70, at 120, 137; Calkins, supra note 77 , at 41718; Chauncey H. Browning, Jr. (1980), Parens Patriae Actions: An Assessment, Antitrust Law Journal, 49(3):10151022, at 1019 .
} 
strategic. Some of the states had already had statutes allowing private actions by or on behalf of indirect purchasers at the time. ${ }^{139}$ Others have adopted such rules either through judicial improvisation or legislative action. Although constitutionality of such state rules was questioned before the Supreme Court, ${ }^{140}$ the Court decided that state indirect purchaser rules did not interfere with the objectives of the federal antitrust policy and therefore were not pre-empted by the federal law. ${ }^{141}$

\section{ACTIONS BY STATE AGs: 1980-2006}

Empirical data relating to the enforcement efforts of the State AGs reveal interesting patterns. Twenty-six cases have been spotted so far which were initiated by the State AGs between the years 1980-2006. ${ }^{142}$ First of all, the data show that Sherman Act $\S$ I type of violations are of more interest to the States than the Sherman Act $\S$ II type of violations. Originally, the literature had predicted that parens patriae actions would mainly focus on price-fixing violations due to the advantageous damage computation methods allowed by federal law. ${ }^{143}$ In practice, however, although still centring around pricing issues in general, the diversity of antitrust problems dealt with by the State AGs is remarkable. Besides eight cases involving price-fixing, the States have brought eight retail price maintenance cases, three involving boycotting, two involving market allocation, two tying cases, one market foreclosure case, and two other cases involving other pricing issues.

\footnotetext{
${ }^{139}$ See e.g. Kevin J. O'Connor, Is the Illinois Brick Wall Crumbling?, 15 ANTITRUST 34 (Summer 2001); Jonathan T. Tomlin, Dale J. Giali (2005), Federalism and the Indirect Purchaser Mess, George Mason Law Review 11(1): 157178.

${ }^{141}$ Id. at 106; For the story behind the Illinois Brick and the California judgments see Andrew I. Gavil (2005), Antitrust Remedy Wars Episode I: Illinois Brick from the Inside the Supreme Court, St. John's Law Review, 79(3): 553-624.

${ }^{142}$ The data analysed in this section are based on the database of National Association of Attorneys General which is still under preparation. Therefore, the cases spotted so far by no means constitute the whole list of the actual cases initiated by the State Attorneys General. However, they still prove to be sufficient to depict the picture of parens patriae activity.

${ }_{43}$ Oliff III, supra note 88 , at 357.
} 
Figure I: Substantive Bases of Actions (1980-2006)

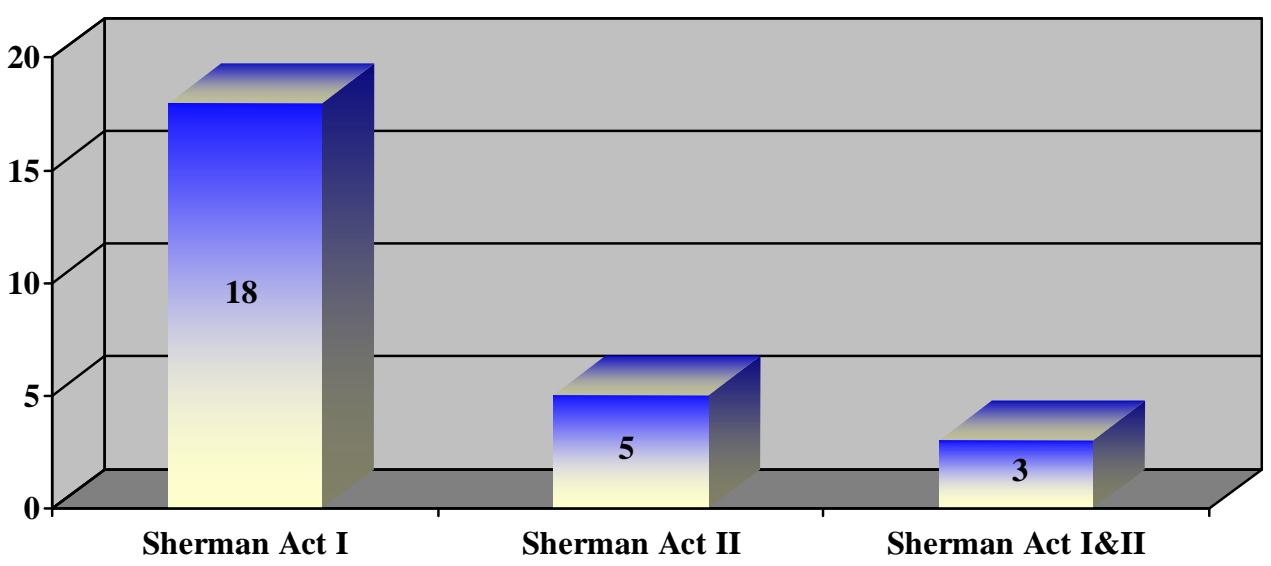

Figure II: Types of Violations (1980-2006)

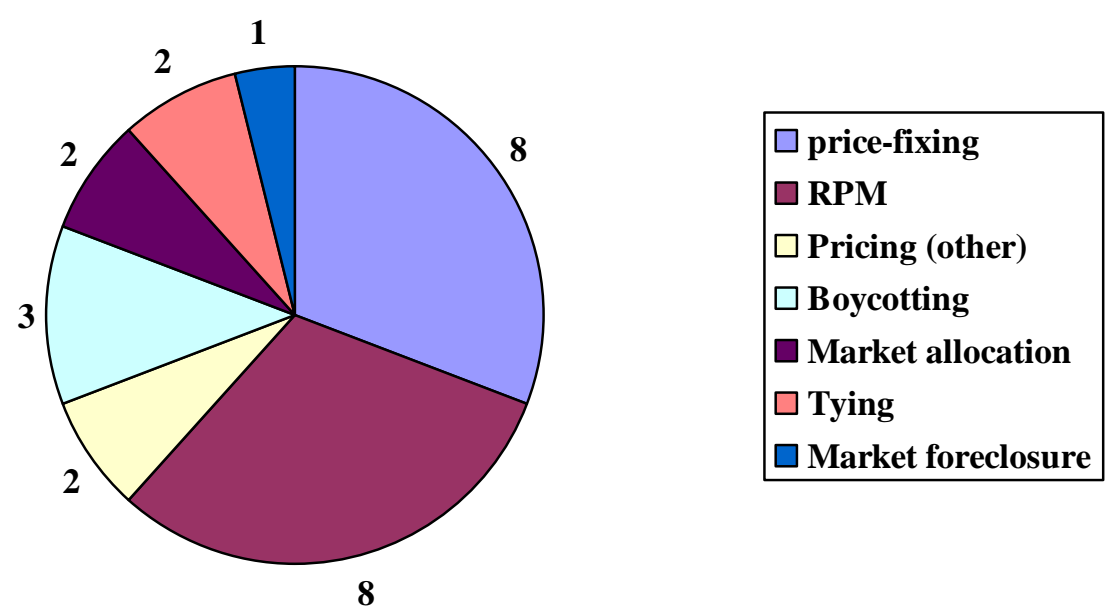

The product markets which those cases involve are equally diverse. Eight cases are related to drug or other healthcare markets, seven to basic consumer products such as CDs or milk, three to intermediary goods, four to electronics, one to automobiles, one to domestic air transportation, one to insurance services, and one to computer operating systems. 
Figure III: Product Markets (1980-2006)

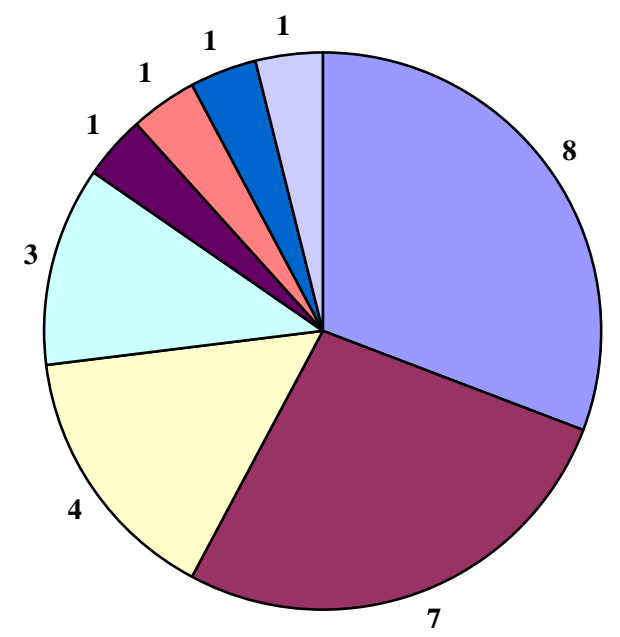

\begin{tabular}{|l|}
\hline healthcare \\
$\square$ consumer products \\
$\square$ electronics \\
$\square$ intermediary goods \\
$\square$ automobiles \\
$\square$ air transport \\
$\square$ insurance \\
$\square$ computer operating systems
\end{tabular}

Another interesting pattern is the degree of inter-state cooperation involved in the investigation and management of antitrust cases. Whereas only two cases were initiated and pursued by the efforts of a single state, thirteen multi-state and eleven nationwide cases were managed by the cooperative efforts of the states. Cooperation with the federal authorities also becomes apparent, particularly when cases initiated after 2000 are concerned. One case was pursued side by side with the criminal investigations of the Department of Justice (DOJ), and in four other cases DOJ was involved through civil investigations. The Federal Trade Commission (FTC), on the other hand, investigated thirteen violations which were brought before the courts by the State AGs. In eight of those cases, the FTC and the State AGs cooperated closely in all stages of investigation including the settlements. In one recent case particularly, the FTC dropped its investigation as it was satisfied with the remedies sought by the State AGs in addressing the violation. 
Figure IV: Inter-State Cooperation (1980-2006)

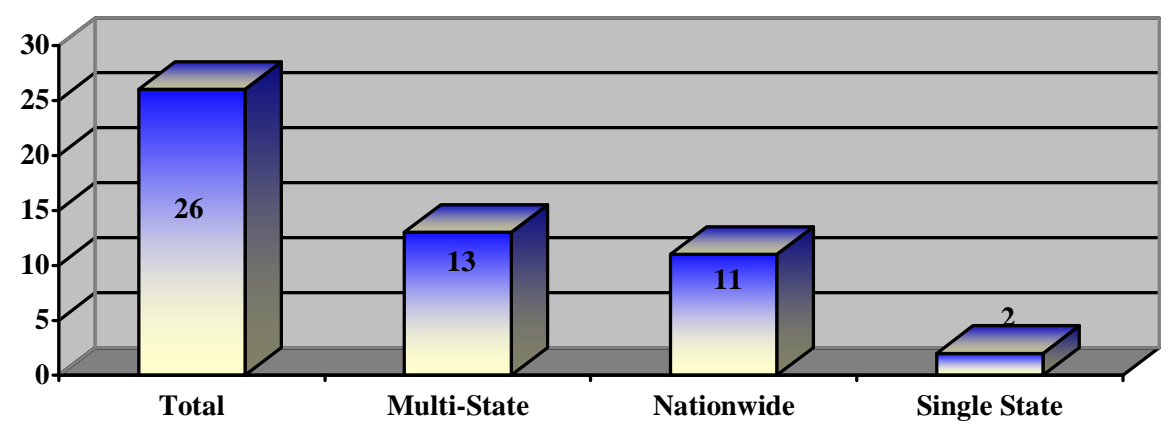

Figure V: Federal-State Cooperation (1980-2006)

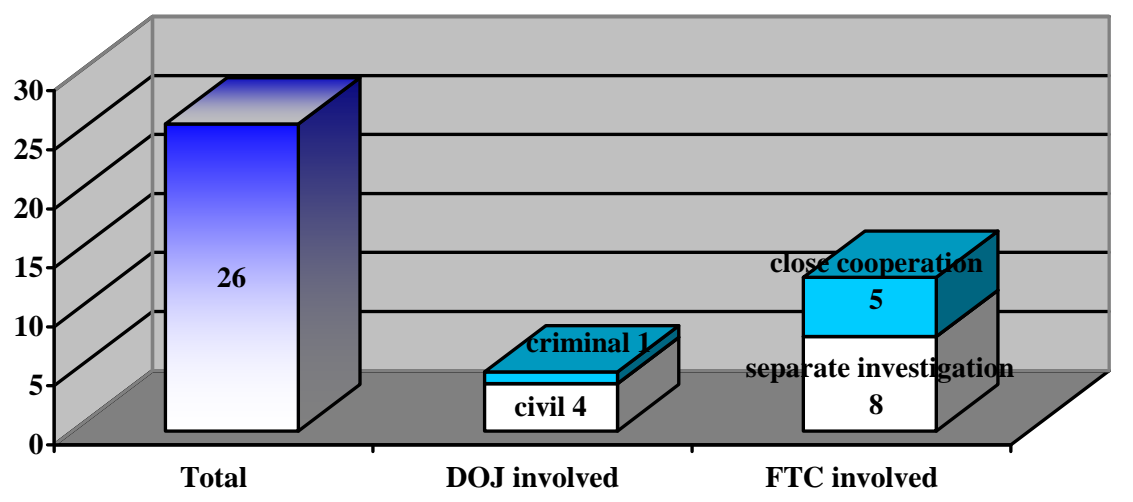

The types of the cases pursued by the State AGs illustrate that they mix and match the opportunities provided by the federal and state laws strategically to secure compensation for the largest class possible. When a case concerns only final consumers as direct purchasers, State AGs choose the federal courts as the main venue and take action utilising the parens patriae mechanism. Between 1980 and 2006 ten cases followed that pattern. When the consumers are not direct purchasers, however, they prefer to bring class actions before the state courts under state indirect purchaser rules. Class actions are also utilised when a case is brought on behalf of competitors or when the states themselves are injured as consumers. Most of the time, however, a single conspiracy causes injury to all of these classes, particularly in healthcare and drug markets. In such cases, class actions and parens patriae suits are brought in collaboration. Between 1980 and 2006, State AGs 
have pursued three class actions as class leaders, ten parens patriae actions, and thirteen parens patriae actions in collaboration with class actions.

Figure VI: Types of Actions (1980-2006)

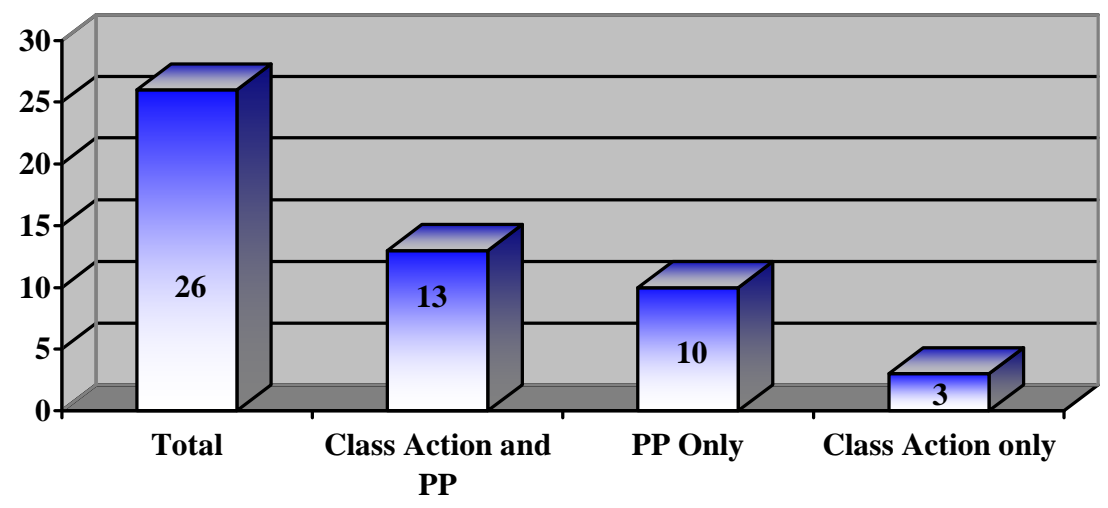

When it comes to distribution of damages, cy pres methods seem to prevail. Only in six cases were damages distributed solely through direct distribution methods. In seven cases direct and cy pres mechanisms were applied together, and in thirteen other cases damages were distributed entirely through cy pres mechanisms which is not surprising considering that most cases involved inter-state or nationwide enforcement efforts to address conspiracies in products of relatively low value and regular consumption such as drugs and basic consumer products.

Figure VII: Distribution of Damages (1980-2006)

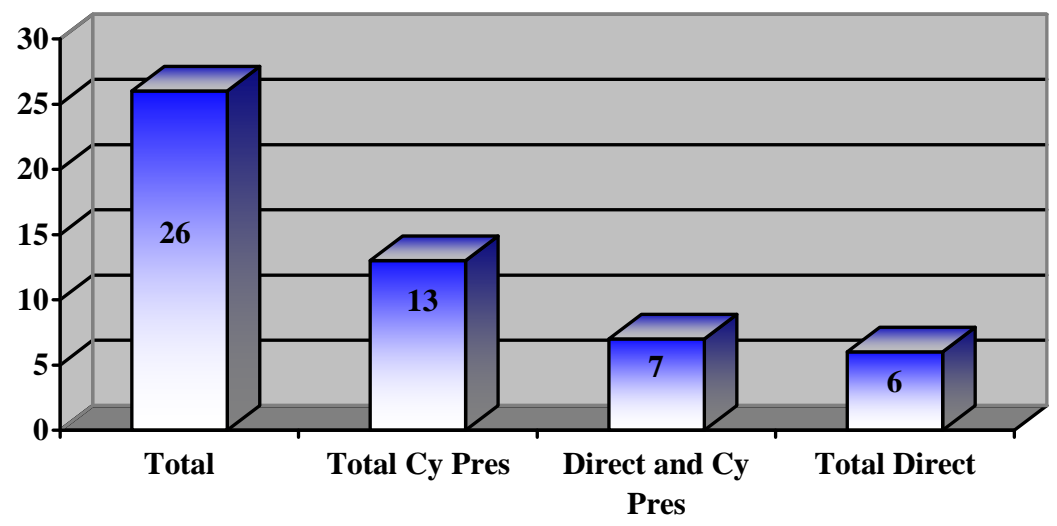

\section{TWO NOTORIOUS CASE EXAMPLES: Tobacco and Microsoft}

Parens patriae activity by the State AGs had attracted only little attention until they reached the master settlement agreement with the tobacco companies in 1998. The degree of inter-state cooperation, the massive amount of recovery 
secured from the industry which had never successfully sued in the federal courts before, and the unprecedented application of the parens patriae doctrine compelled both the public and the legal community to consider what the states had been doing under the position of parens patriae. ${ }^{144}$ Tobacco litigation was a tort case, and its subject matter was not antitrust. However, it is relevant to discuss here, albeit briefly, as its impacts went beyond its subject matter.

The master settlement agreement was reached as a result of 40 cases brought by 46 States to recover the cost the smokers had caused to their Medicaid systems. With the settlement agreement, the States together secured around $\$ 206$ billion as compensation and the private lawyers they had hired received around $\$ 9$ billion in attorney fees. ${ }^{145}$ First of all, it was argued that employment of parens patriae in this case went far beyond the original purposes of the doctrine. The doctrine originally enshrines a sovereign's prerogative on the wellbeing of those living under his sovereignty. In the tobacco case, however, smokers had not even been mentioned and what the States were in reality concerned about was how to recover their own costs. ${ }^{146}$ As a result, what the companies were issued was not compensation, but a kind of a tax which the consumers would bear eventually. ${ }^{147}$ Therefore, the State AGs were criticised heavily for using the parens patriae mechanism for the proprietary interests of the States and the benefit of their attorneys. Besides, some provisions of the agreement argued to give competitive advantage to the settling companies against their current and future rivals. ${ }^{148}$ Hence, it was believed that as a result of the settlement agreement, everyone was better off - including the States, attorneys, even tobacco companies -

\footnotetext{
${ }^{144}$ leyoub, Eisenberg, supra note 30, at 1860-62.

${ }^{145}$ In fact due to the complexity of the litigation and the settlement agreement, and also the unprecedented amount of damages, the National Association of Attorneys General (NAAG) has established a separate project to enforce the master settlement agreement. Eight years after the settlement, the project is still in force today to distribute damages. See http://www.naag.org/issues/tobacco/index.php?sdpid=399.

${ }_{146}$ Thomas C. O'Brien, Constitutional and Antitrust Violations of the Multistate Tobacco Settlement, Policy Analysis, No.371, May 18, 2000, at 2; Regulation By Litigation: The New Wave of Government-Sponsored Litigation, Center for Legal Policy at the Manhattan Institute, Conference Proceedings June 22, 1999, Washington, D.C., Manhattan Institute Conference Series No.1, Panel Two: The Politics and Economics of Government Sponsored Litigation, Remarks by Prof. Lester Brickman, at 29.

${ }_{147}$ O'Brien, id.; Regulation By Litigation, id., Remarks by Prof. John Langbein, at 42.

${ }^{148}$ O'Brien, id., at 3-5;
} 
except the consumers. Naturally in such a case, concerns about corruption were also pronounced. ${ }^{149}$

Another case - this time in the field of antitrust - that was highly debated, both in terms of substantive analysis and enforcement tendencies, came in 2001 when nineteen states and the DOJ sued the Microsoft Corporation for monopolisation in the computer operator systems market and attempted monopolisation in the interfaces market. ${ }^{150}$ In this case damages were not sought; rather it was the divergence between the injunctive remedies suggested by the DOJ and the State AGs which set the headlines. As a result of complex litigations in different venues, the DOJ, AGs of nine States ${ }^{151}$ and the Microsoft cooperation reached an agreement on settlement in $2002 .^{152}$ Ten other states, ${ }^{153}$ however, were not satisfied by the remedies imposed in the settlement agreement and pursued further litigation to secure additional injunctive remedies, including compulsory licensing of interfaces. In response to the prayer of the litigating States for further remedies, Microsoft argued that for a variety of constitutional reasons, in the cases of national scale states should not be allowed to pursue remedies independent of the federal authorities. ${ }^{154}$ The court rejected this argument by making it clear that for the purposes of the federal courts it does not make any difference whether it is the federal authorities, State AGs or even private parties who seek remedies against violations of federal antitrust law. ${ }^{155}$ As they are all authorised by federal law, their enforcement activities carry equal weight in the eyes of the federal courts. ${ }^{156}$

The DOJ has filed an amicus brief against the arguments of Microsoft which interestingly depicts the enforcement environment which the DOJ desires. In its brief, the DOJ disagreed with Microsoft in principle, and defended the

\footnotetext{
${ }^{149}$ Regulation By Litigation, supra note 146, remarks by Prof. Lester Brickman, at 31.

150 U.S. v. Microsoft Corp., 97 F.Supp.2d 59 (2000); 87 F.Supp.2d 30 (2000), denying appeal remanding cause 530 U.S. 1301 (2000), rehearing denied 253 F.3d 34 (2001), remanding 231 F.Supp.2d 144 (2002), denying certiorari 534 U.S. 952 (2001).

${ }_{151}$ New York, Ohio, Illinois, Kentucky, Louisiana, Maryland, Michigan, North Carolina, Wisconsin (the settling States).

152 U.S. v. Microsoft, 231 F.Supp.2d 144 (2002).

${ }^{153}$ California, Connecticut, the District of Columbia, Florida, lowa, Kansas, Massachusetts, Minnesota, West Virginia (the litigating States).

${ }^{154}$ Memorandum of Defendant Microsoft Corporation in Support of its Motion for Dismissal of the Non-Settling States' Demand for Equitable Relief, Civil Action No.98-1233 (filed Feb. 26, 2002).

${ }_{155}$ State of New York, et. al. v. Microsoft Corp., F.Supp.2d 132 (D.D.C. 2002), at 148-152.

${ }^{156} \mathrm{Id}$.
} 
state's involvement in the enforcement of federal antitrust policy. ${ }^{157}$ However, it further argued that in cases of national scale, when the views of the states and the federal authorities collide, federal authorities should have the prerogative, and their suggestions should outweigh those of the states. ${ }^{158}$ Arguably, this proposal of the DOJ illustrated that it desired a position for the federal authorities resembling that of the European Commission in antitrust enforcement. In other words, initiatives of the states were welcome as long as they contributed to the cases of the federal authorities, but at the end of the day it should be the federal authorities who would have the last word and give direction to the federal policy.

In the Microsoft case, the litigating States were led by California - the home of Silicon Valley - and almost all of the substantial competitors of Microsoft. Therefore, although the remedies they sought were eventually rejected, and the federal courts approved the original settlement offered by the DOJ, ${ }^{159}$ this case overshadowed the reputation of the State AGs in the field of antitrust. They received heavy accusations of acting for parochial and political reasons. ${ }^{160}$ Although nine other States, led by New York, cooperated with the DOJ throughout the litigation and contributed substantially to the case, especially by providing evidence including detailed economic analyses and the deposition of Bill Gates, ${ }^{161}$ they did not get any credit for that. What was mostly discussed was not what the States had done right, but what they had done wrong.

\section{STATES in the AGENDA of the ANTITRUST MODERNIZATION COMMISSION}

After the Microsoft case, enforcement of federal antitrust laws by the State AGs attracted considerably more attention. It was questioned whether the

\footnotetext{
${ }^{157}$ Memorandum Amicus Curiae of the United States Regarding Microsoft Corporation's Motion for Non-settling States' Demand for Equitable Relief, Civil Action No.98-1233 (filed Apr.15, 2002).

${ }^{158}$ Id. at $9-17$.

159 State of New York, et. al. v. Microsoft Corp., 224 F.Supp.2d 76 (D.D.C. 2002); Commonwealth of Massachusetts v. Microsoft Corp., 373 F.3d 1199 (D.C.Cir. 2004)

${ }^{160}$ California particularly was accused of being captured by AOL and Sun Microsystems, see Robert W. Hahn, Anne Layne-Farrar (2003), Federalism in Antitrust, Harvard Journal of Law and Public Policy 26(3): 877-923, at 892-93.

${ }_{161}$ See e.g. Jay L. Himes (2002), Exploring the Antitrust Operating System: State Enforcement of Federal Antitrust Law in the Remedies Phase of the Microsoft Case, George Mason Law Review 11(1): 37-111, at 51-54; Robert L. Hubbard, Pamela Jones Harbour (2002), "Antitrust Law in the New York State", LexisNexis, New York, at 17-19.
} 
chief legal officers of the states should be able to challenge a national champion like Microsoft and to bring their own views, which are at times inconsistent with the views of the federal authorities to the federal enforcement scheme. In particular, Richard Posner, who had previously been appointed as a mediator by the federal court in the Microsoft litigation, wrote an article where he inter alia expressed his frustration about the States' presence in the federal antitrust enforcement structure. ${ }^{162}$ In his article, on the basis of his experience as the mediator of the Microsoft litigation and a federal judge, he argued that the State AGs lack the necessary financial and human resources to enforce federal antitrust laws, and clearly they fail to understand the dynamics of newly emerging technical markets such as computer software. ${ }^{163} \mathrm{He}$ further contended that State AGs were basically free-riding on the efforts of the federal authorities to bring forward meritless cases on parochial grounds. ${ }^{164}$

Eventually, the Antitrust Modernization Commission, which was founded in 2002 to study the effectiveness of US antitrust system in general, including both substantive and enforcement issues, included state enforcement of federal antitrust laws in its agenda. Besides analysing state enforcement directly, the Commission is conducting other studies which indirectly relate to state enforcement, such as the federal indirect purchasers rule.

\section{A. Parens Patriae before the Commission}

It appears that, when it comes to parens patriae actions against Sherman Act violations, there is more concern about the requests by the states for injunctive relief than treble damages. State AGs are the only authorities empowered to seek damages on behalf of consumers under federal law. ${ }^{165}$ Therefore, actions for damages are the exclusive domain of the State AGs, and inconsistency between the views of the federal authorities and the State AGs is less likely to occur. Besides, enforcement efforts of the State AGs in

\footnotetext{
162 Richard A. Posner (2001), Antitrust in the New Economy, Antitrust Law Journal 68(3): 925-945.

${ }^{163}$ Id., at 941.

164 Id.

${ }^{165}$ The authority of FTC to seek permanent injunction is interpreted to include disgorgement of illegal profits, see

FTC v. Mylan Laboratories, Inc., 62 F.Supp.2d 25 (D.D.C., 1999). However, the scope of disgorgement as a remedy does not comprehend to that of compensation, and the FTC rarely uses this authority in the context of antitrust.
} 
practice are appreciated and praised both for providing relief to consumers and detecting violations which have escaped the attention of the federal authorities. ${ }^{166}$ After all, it is believed that the states have been performing their duty in line with the objectives of the Congress, and those objectives would remain largely unfulfilled if the states were to leave the stage. ${ }^{167}$

When it comes to the injunctive remedies, however, divergence between the views of the State AGs and the federal authorities is more likely to occur as both authorities are empowered by federal law to seek such remedies. Within this context, divergence generally refers to State AGs feeling unsatisfied with the remedies imposed by the federal authorities and litigating the issue further, as happened in the Microsoft case. Federal law does not provide any mechanism to solve such conflicts as neither authority is given superiority over the other. Ultimately, as a matter of principle, it is questioned whether it is appropriate to let the legal officers of the states get involved in the federal antitrust structure and bring their own view, particularly when nationwide markets are at stake.

As a result of its proceedings, the Antitrust Modernization Commission has decided to bring forward three alternatives to enhance the effectiveness of allocation of duties between the federal authorities and the State AGs. ${ }^{168}$ The first alternative suggests restricting the parens patriae authority to strictly local matters. ${ }^{169}$ The second alternative proposes restricting it to certain types of substantive issues. ${ }^{170}$ According to this alternative, types of violations on which the federal policy is clear and stable - such as price-fixing and other hard-core violations - would be open to the State AGs, whereas more controversial issues, such as the vertical restraints where disagreement between the views of the State AGs and federal authorities is more likely to occur, would be the exclusive domain of the federal authorities. The third

\footnotetext{
${ }^{166}$ See e.g. Harry First (2001), Delivering Remedies: The Role of the States in Antitrust Enforcement”, George Washington Law Review, 69:1004-1041.

167 Id., at 1005.

${ }^{168}$ Antitrust Modernization Commission, Enforcement Institutions-States Discussion Memorandum, available at http://www.amc.gov/pdf/meetings/Enflnst State DiscMemo pub.pdf.

169 Id., at 22.
170 Id., at 23.
} 
alternative proposes a formal mechanism where the State AGs would ask for the permission of the federal authorities before initiating litigation. ${ }^{171}$

The first alternative seems to ignore the dynamics of the parens patriae mechanism. As explained in detail above, ${ }^{172}$ the rationale behind the recognition of parens patriae authority by the HSR Act was to create an additional mechanism for the enforcement of federal antitrust laws which performs two tasks at the same time; providing relief to consumers, and detecting conspiracies which escape the attention of the federal authorities. This rationale represents a departure from the logic of the earlier American parens patriae doctrine which offered a peaceful way for states to protect their economic interests for the sake of federalism. Restricting parens patriae authority to local matters would mean a return to the traditional parens patriae doctrine which has little merit and justification at best, in a modern united country where the objective of federalism has already been achieved. This proposal is also inconsistent with the practical patterns of parens patriae cases. As it is shown above, most of the parens patriae cases brought by the State AGs since the 1980 s are either of multi-state or national dimension. ${ }^{173}$ Therefore, practically, restricting parens patriae authority to local matters would have the same effect as abolishing the mechanism totally. Before taking such a dramatic action, the Modernization Commission should engage in detailed empirical analysis to ascertain the function of the State AGs in detecting and deterring nation-wide conspiracies. Otherwise, preclusion of state enforcement could dramatically impede the effectiveness of federal antitrust enforcement. In addition, the first alternative also seems to miss the work division between the federal and state antitrust laws. The states have their own antitrust statutes to address local concerns. Thus, if restricted to local matters, parens patriae enforcement of federal antitrust laws would be retarded to nothing more than an unnecessary duplication of state laws.

The second alternative offers a less dramatic change than the first alternative, although it is no less provocative in terms of the political questions it poses.

\footnotetext{
${ }^{171}$ Id., at 24.

172 See supra p.22.

${ }^{173}$ See figure IV on supra p.34.
} 
First of all, it is not certain how the substantive antitrust issues would be divided into two strands as "controversial" and "less controversial". It is not certain whose angle and which principles would be utilised in such analysis. If anything, such analysis could hardly be conducted in an objective way. The Commission is also silent on how to solve the practical problems this alternative is likely to raise. After all, in antitrust practice, authorities generally face cases where different kinds of violations become intertwined. Only a few cases involve one type of violation which is easily identifiable. Moreover, in some cases it becomes controversial to identify the particular type of violation, and decisions can only be reached in the later stages of litigation after complex legal and economic analyses. However, if the second proposal is to be implemented the courts will have to ascertain the type of violation at the outset of the litigation in order to decide whether the State AGs have standing or not. Most importantly, this alternative would lead to an unjustifiable discrimination among the consumers and the undertakings. In other words, why would the victims of monopolization or retail price maintenance be denied the benefit of parens patriae, whereas the victims of price-fixing would not? Or thinking from the opposite angle, why could the conspirators involved in monopolization or retail price maintenance escape compensation through parens patriae actions whereas price-fixers could not? In any case, the Commission should consider cautiously whether it is appropriate to cause a substantive inequality between the consumers and undertakings when trying to fix an enforcement problem.

The third alternative seems to be the most provocative as it proposes novel unequal positions for the enforcers of federal antitrust law. First of all, it is against any kind of legal principle one can think of, as it requires the permission of an administrative body for the exercise of the right to be heard before the judiciary. Furthermore, the degree of discretion that the federal authorities would enjoy in deciding whether to accept or to decline such requests is uncertain. In other words, would it be totally up to the perceptions of the federal authorities to bar state enforcement whenever it suits them or would such discretion be restricted to certain cases, e.g. when the federal authorities have been dealing or have already dealt with the same case? In 
any case, it is obvious that such decisions could hardly be objective and there would be room for political manoeuvre by the federal authorities. Even if the federal authorities are less prone to being captured by the industrial interests, they are not totally free from pressure. Besides, they might end up in underenforcement simply as a result of a mistake in their evaluation. In such cases, if the State AGs would not be allowed to bring additional cases, who will guard the guards then?

Taking a step backwards and having a look at the problem on a more general scale, the trend of federal enforcement seems to be largely ignored by the Modernization Commission. Parens patriae actions by the State AGs have shown a progressive development since the 1980s. The State AGs have discovered inter-state cooperation in the 1980s and since the 1990s there has been vigorous cooperation between the federal authorities and the State AGs. It seems that the antitrust agenda of the State AGs mostly overlaps with that of the FTC rather than that of the DOJ. In five cases, all investigated in the late 1990s, there was close cooperation between the FTC and the State AGs. In a very recent case moreover, the FTC decided to drop its investigation as its concerns were sufficiently addressed by the State AGs. ${ }^{174}$

The only notable exception to that trend seems to be the Microsoft case which dominated the discussions due to the scale and nature of the market and the undertakings involved. However, even in that case, there was no entire clash between the views of the States and the DOJ. Whereas nine of the State AGs cooperated with the DOJ vigorously, ten others decided to pursue more stringent remedies. Even if this case could be seen as a disturbing example, discrepancies can be prevented with less dramatic precautions than leaving the parens patriae mechanism totally redundant.

At this point, it appears inappropriate to leave the courts totally out of the agenda when discussing the effectiveness of federal antitrust enforcement. There seems to be a consensus that the problem posed by the State AGs is

\footnotetext{
${ }^{174}$ Remeron End-Payor Antitrust Proceedings (2005), see FTC's statement at http://www.ftc.gov/opa/ 2004/10/organon.htm.
} 
one of over-enforcement. However, as explained above, due to the silence of federal law, the courts employ the standards developed within the context of class actions in parens patriae cases particularly when reviewing settlement agreements. ${ }^{175}$ This analogy seems inappropriate, since the main danger within the context of class actions is one of under-enforcement. Hence, the problem of over-enforcement could very well be addressed through incorporation of a judicial review standard tailored to the dynamics of parens patriae actions into federal law. Conflicts between the federal authorities and the State AGs could also be given merit within the context of such a standard. For instance, the State AGs could be compelled to bring forward extra evidence and economic arguments to convince the courts that the remedies imposed by the federal authorities fall short of addressing antitrust violations in any specific case and justify their actions. The courts could be given the authority to reject the actions by the State AGs on the basis that in a particular case, the concerns brought forward have already been sufficiently addressed and therefore, actions by the State AGs have been pre-empted.

In summary, opposition against the State AGs pools around the argument that, particularly in terms of the injunctive remedies they seek, the State AGs cause over-enforcement. However, considering the lack of empirical evidence on the actual costs imposed by state enforcement, the Modernization Commission should not rush to conclusion. The parens patriae mechanism has large potentials both as a source of redress to consumers and deterrence to business, and therefore, dramatic proposals setting this mechanism aside appear to be unfounded, particularly in the face of the constantly improving trend towards cooperation between the federal authorities and the State AGs. Leaving the judiciary totally out of the discussion is another handicap, when the dangers of over-enforcement and inconsistency could easily be solved through adoption of a judicial review standard tailored to the dynamics of parens patriae cases.

\footnotetext{
${ }^{175}$ See supra p.27.
} 


\section{B. Indirect Purchasers Rule}

Another issue before the Modernization Commission, with probable impacts on enforcement efforts of the State AGs, is the position of indirect purchasers. ${ }^{176}$ As explained above, under federal law, indirect purchasers cannot seek treble damages. ${ }^{177}$ However, most of the state antitrust laws recognise the right of the indirect purchasers to obtain treble damages which the Supreme Court did not find unconstitutional. ${ }^{178}$ As the data given in the empirical part indicate, the State AGs play an active role in providing compensation to the indirect purchasers through actions under state antitrust laws. ${ }^{179}$ As a result, the danger of multiple recoveries which the Supreme Court aimed to avoid in Illinois Brick becomes exacerbated in practice, as the direct and indirect purchasers seek damages in different venues which render coordination between the courts to prevent multiple recoveries almost impossible. ${ }^{180}$ In order to solve this dilemma, the Modernization Commission has correctly added the issue of indirect purchasers into its agenda.

The first alternative which the Modernization Commission proposes to solve the puzzle is to preempt the state rules providing standing to indirect purchasers. ${ }^{181}$ If adopted, this alternative would prevent the indirect purchasers from bringing damage actions both in federal and state courts. However, mainly due to considerations of federalism, this alternative is believed to be politically unfeasible and therefore the least likely to be realised. ${ }^{182}$ The second alternative is to repeal the Illinois Brick rule and to preempt the state laws, so that all actions by both direct and indirect purchasers could be brought before the federal courts in order to prevent multiple recoveries and distribute damages between indirect and direct

\footnotetext{
${ }^{176}$ Substantive and economic analysis of the actions for damages by the indirect purchasers is out of the scope of this paper. Rather, the discussion will be limited to the impact of any modification on the enforcement efforts of the State AGs.

177 Illinois Brick, supra note 133.

${ }^{178}$ ARC America, supra note 139.

179 See figure VI on supra p.35.

${ }^{180}$ Tomlin, Giali, supra note 139, at 177; Calkins, supra note 77, at 574

181 Antitrust Modernization Commission, Civil Remedies-Indirect Purchasers Discussion Memorandum, May 4 2006, available at http://www.amc.gov/pdf/meetings/CivRem-IndP DiscMemo060504-fin.pdf, at 22.

182 Transcripts of Public Hearing on Indirect Purchasers Actions, available at

http://www.amc.gov/commission hearings/pdf/050627 Indirect Purchaser Transcript reform.pdf, remarks by

Margaret M. Zwisler, at 11; Statement of Margaret M. Zwisler, available at

http://www.amc.gov/commission hearings/pdf/Zwisler.pdf, at 1; Statement of David Tulchin, available at

http://www.amc.gov/commission hearings/pdf/Tulchin.pdf, at 13.
} 
purchasers through a single action. ${ }^{183}$ However, the political opposition to preemption still stands, and becomes even stronger under this second alternative. If Illinois Brick was repealed, there would be no conflict between the federal and state laws, and therefore no merit for pre-emption of state law. The third alternative is to repeal Illinois Brick, not to preempt state law, and through amendment of federal procedural rules to require transfer of state cases to the federal courts under certain circumstances, so that damages could be distributed among the direct and indirect purchasers to prevent multiple recoveries. ${ }^{184}$ Among three alternatives, the last seems to be the most likely to be adopted.

From the angle of enforcement by the State AGs, only the first alternative offers a substantial change. In such case, there would be no forum left for the State AGs to bring actions on behalf of indirect purchasers, and therefore, consumers could only benefit from the actions of the State AGs in a relatively low number of cases where they are direct purchasers. The second and third alternatives on the other hand are likely to contribute to the enforcement efforts of the State AGs, albeit slightly. Currently the State AGs already bring actions on behalf of indirect purchasers under state law in the state courts through class or parens patriae actions depending on whichever is recognised by the state law and provides more advantageous mechanisms. However, since those cases are brought before different forums under different laws, inter-state cooperation appears to be more burdensome compared to parens patriae actions under federal law. If adopted, the second and the third alternatives would confer the State AGs the possibility of bringing parens patriae cases under federal law in federal courts on behalf of indirect purchasers. Such development would increase the number of multistate and nationwide cases on behalf of indirect purchasers, and the possibility of redress to final consumers. Ultimately, however, the actual effect of any change in the federal policy regarding indirect purchasers would depend on the Modernization Commission's final position on the role of the State AGs. Nevertheless, from the state enforcement point of view, the

\footnotetext{
183 Antitrust Modernization Commission Momerandum, supra note 181, at 23

184 Id., at 25.
} 
Commission's current proposals seem inconsistent at best, as its proposals suggest restricting the parens patriae authority on the one hand, and levelling the playing field of the State AG in the context of indirect purchasers rule on the other.

\section{CONCLUSIONS}

The office of the State AG holds a unique position in the mainstream of state politics. Its main source of authority to enforce federal antitrust laws is the doctrine of parens patriae which experienced substantial transformation over time to become a mechanism of providing redress to consumers and deterrence against antitrust violations, whereas it was originally employed by the Supreme Court to solve conflicts of federalism. As foreseen by federal law, parens patriae mechanism gives the State AGs considerable discretion in every stage of enforcement, including the distribution of damages. As a result, parens patriae actions prove to be more advantageous than any other mechanism in providing relief to a mass.

In practice, the type of violations and the markets that the State AGs target show considerable variety. Besides, there is constant development towards interstate and federal-state cooperation. The State AGs mix and match channels of state and federal law to enhance their enforcement agenda as much as possible. Therefore, it is fair to say that during the last three decades since the passage of the HSR Act, the State AGs have gained substantial experience and expertise in actions on behalf of consumers and distribution of damages.

The Antitrust Modernization Commission proposes different alternatives which would all change the federal enforcement structure dramatically. However, those proposals seem to be unfounded in the face of the practical patterns of state enforcement. Less dramatic alterations such as adoption of clear judicial review standards could address the threat of over-enforcement and conflicts between the State AGs and the federal authorities. Removing the State AGs from the federal stage totally is neither the only alternative nor the most desirable one. 